\title{
Diastereoselective Synthesis of Bridged Polycyclic Alkaloids via Tandem Acylation/Intramolecular Diels-Alder Reaction
}

\author{
Chih-Hau Chen, Gorakh S. Yellol, Cheng-Hsun Tsai, Prashant B. Dalvi, and Chung-Ming Sun* \\ Department of Applied Chemistry, National Chiao Tung University, Hsinchu 300-10, Taiwan, Republic of China \\ Supporting Information
}

ABSTRACT: A mild and efficient stereoselective synthesis of hexacyclic indole alkaloids with a tetrahydro- $\beta$-carboline motif has been developed by utilizing the Pictet-Spengler reaction and tandem $\mathrm{N}$-acylation followed by intramolecular DielsAlder cyclization. Initially, a diene unit was installed in the tetrahedron $\beta$-carboline skeleton through Pictet-Spengler cyclization of the corresponding aldehyde with tryptophan ester. The dienophile moiety was introduced by $\mathrm{N}$-acylation of

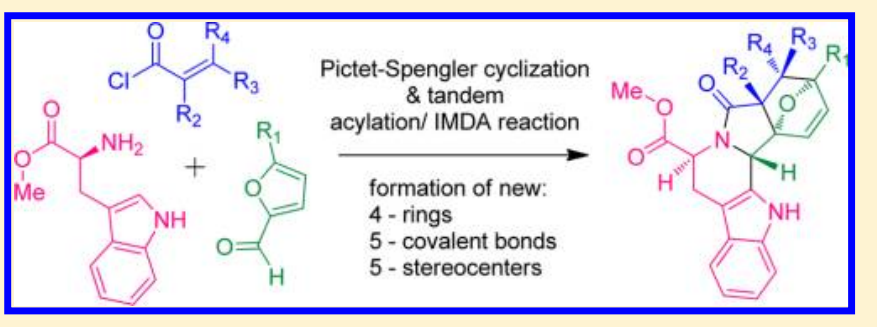
tetrahydro- $\beta$-carboline. Successive, in situ, $[4+2]$ intra-

molecular Diels-Alder cycloaddition of the activated dienophile and conjugated diene containing intermediate furnished bridged polycyclic heterocycles with high diastereoselectivity. Formation of four new rings, five new covalent bonds, and five new chiral centers with excellent stereoselectivity is the key feature of this strategy. The diastereoselective formation of product was attributed to intramolecular chirality transfer through a chiral amino acid. The stereoselective outcome of this tandem reaction was confirmed by X-ray crystallographic studies. The developed synthetic strategy was also explored on a soluble polymer support to incorporate the advantage of rapid synthesis and a high-throughput workup process toward the development of a green synthetic protocol for polycyclic alkaloids.

\section{INTRODUCTION}

Heteroatom-embedded polycyclic molecules have played a prominent role in the history of organic chemistry and continue to be an important source of medicines in the pharmaceutical industry. ${ }^{1}$ The complexity and diversity of small molecule scaffolds and their functional groups have been an inspiration for chemists to devise novel strategies of synthesis to explore biology systematically. ${ }^{2}$ Multicyclic ring systems, particularly those containing tetrahydro- $\beta$-carboline, exhibit a broad spectrum of biological activities. Tetrahydro- $\beta$-carboline skeletal yohimbine (I) is a potent $\alpha_{2}$ adrenoreceptor antagonist. ${ }^{3}$ Similarly, reserpine (II) also exhibits antihypertensive activity and a sedative property. ${ }^{4}(+)$-Quebrachidine (III) is reported to possess psychosedative and adrenergic activity, and profitably its analogues possess high complexity with great potential to access the diversity of lead structures for drug discovery $^{5}$ (Figure 1). However, the biological activities of this type of bridged polycyclic rigid ring system are less explored. Hence, the design, synthesis, and biological application of multicyclic indole alkaloids with an embedded bridged skeleton have attracted our attention.

Stereoselective construction of multiple chiral centers and rings in a single step is a very fascinating and synthetically useful strategy for rapid assembly of complex polycyclic natural and unnatural molecules. The key toward this strategy is the use of tandem reaction in which multiple reactions are combined into one synthetic operation. Tandem reaction is the optimum methodology for rapid access of fused and complex polycyclic skeletons. ${ }^{6}$ Recently, Tanaka and co-

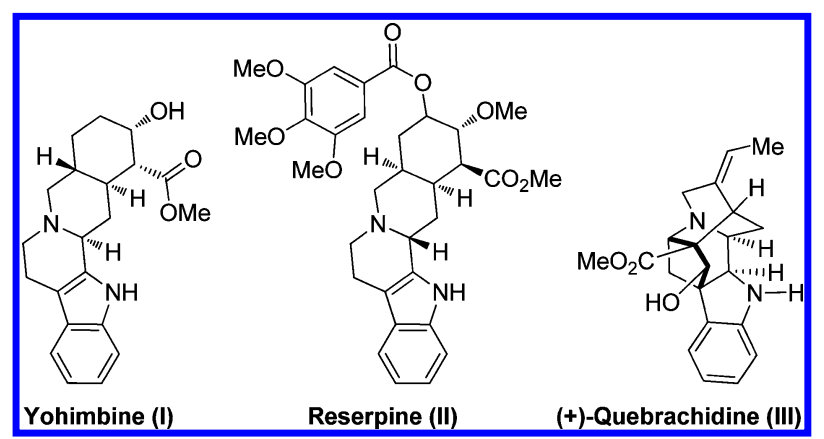

Figure 1. Tetrahydro- $\beta$-carboline-containing bioactive multicyclic ring systems.

workers described the tandem cycloaddition/intramolecular Diels-Alder reaction of alkynes and amide-linked dienes. ${ }^{7}$ Ruijter and Orru reported asymmetric synthesis of synthetic alkaloids by a tandem biocatalysis/Ugi/Pictet-Spengler cyclization sequence. ${ }^{8}$ Since their discoveries, the Pictet-Spengler reaction and Diels-Alder reaction have been intensively studied for the synthesis of fused polycyclic skeletons and natural product synthesis due to their tolerance of diverse functionalities and structural breadth of reaction partners. ${ }^{9}$ The intramolecular Diels-Alder (IMDA) reaction is a powerful strategy for the construction of complex multicyclic skeletons, while the Pictet-Spengler reaction is an important laboratory

Received: July 3, 2013

Published: September 5, 2013 
method for the synthesis of tetrahydro- $\beta$-carbolines (THBCs) and six-membered carbocycles with structural motifs in a diverse array of polyheterocycles. Previously, we have reported the Pictet-Spengler cyclization of various aldehydes with tryptophan to generate THBC scaffolds. ${ }^{10}$ In continuation, the stereoselective synthesis of multicyclic indole alkaloids was envisioned via sequential Pictet-Spengler cyclization, $N$ acylation, and intramolecular Diels-Alder reaction (Figure 2).

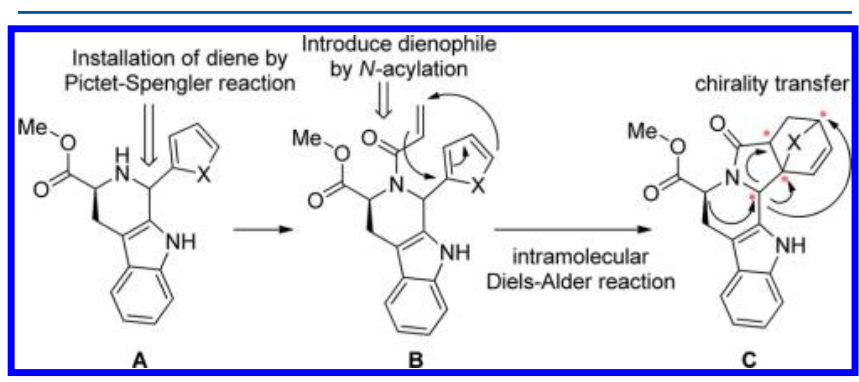

Figure 2. Synthetic strategy toward the bridged multicyclic ring skeleton.

The postulated synthetic route constitutes the installation of a diene motif in the tetrahedron $\beta$-carboline skeleton by PictetSpengler reaction. The dienophile moiety can be introduced by $N$-acylation of tetrahydro- $\beta$-carboline $\mathbf{A}$. The activated dienophile and diene-containing intermediate $\mathbf{B}$ are expected to undergo $[4+2]$ intramolecular Diels-Alder cycloaddition to provide a novel bridged multicyclic architecture, C. Moreover, it was contemplated that the successive chirality transfer from an optically active amino acid can lead to a stereoselective Diels-Alder cycloaddition product. ${ }^{11}$ This approach would allow for rapid and efficient construction of structurally and stereochemically complex molecules with multiple rings and chiral centers under mild conditions in a tandem fashion from readily available chiral amino acids, which is extremely valuable in organic synthesis.

In our continuing research on the synthesis of biologically interesting small heterocyclic molecules, ${ }^{12,13}$ here we report an efficient stereoselective synthesis of hexacyclic indole alkaloids via Pictet-Spengler cyclization and tandem acylation/intramolecular Diels-Alder reaction.

\section{RESULTS AND DISCUSSION}

In line with the planned strategy, our first aim was the installation of a diene motif in the $\beta$-carboline skeleton by Pictet-Spengler reaction. Accordingly, L-tryptophan 1 was treated with 5 -substituted furan-2-carbaldehyde $\mathbf{2}$ in the presence of trifluoroacetic acid in refluxing chloroform for 6 $\mathrm{h}$ or in a microwave cavity for $20 \mathrm{~min}$ at $100{ }^{\circ} \mathrm{C}$ to furnish the desired tetrahydro- $\beta$-carboline 3 (Scheme 1). The resulting mixture of diastereomers 3 was inseparable by column chromatography, hence proceeding with further reaction as a diastereomeric mixture. The ratio of cis/trans diastereomers was $1: 1.15$, which was determined directly by proton NMR of compound 3 (the representative spectral data of cis/trans diastereomers $3\left(\mathrm{R}^{1}=\mathrm{H}\right)$ are provided in the Supporting Information). With the successful installation of furan as a diene motif in the skeleton, the next step was to introduce the dienophile moiety at the secondary nitrogen of $\beta$-carboline. It was decided to introduce a reactive acrylic group through $N$ acylation for the initial studies. Consequently, the diastereomeric mixture of tetrahydro- $\beta$-carboline 3 was treated with acryloyl chloride and its substituted derivatives at ambient temperature in dichloromethane with triethylamine. We found that $N$-acylation of 3 with acryloyl chloride afforded $\alpha, \beta$ unsaturated amide $\mathbf{4}$ at room temperature, which spontaneously underwent intramolecular [4 + 2] Diels-Alder cycloaddition in one pot. The tandem reaction of acylation followed by the

Scheme 1. Synthesis of Hexacyclic Indole Alkaloids 5

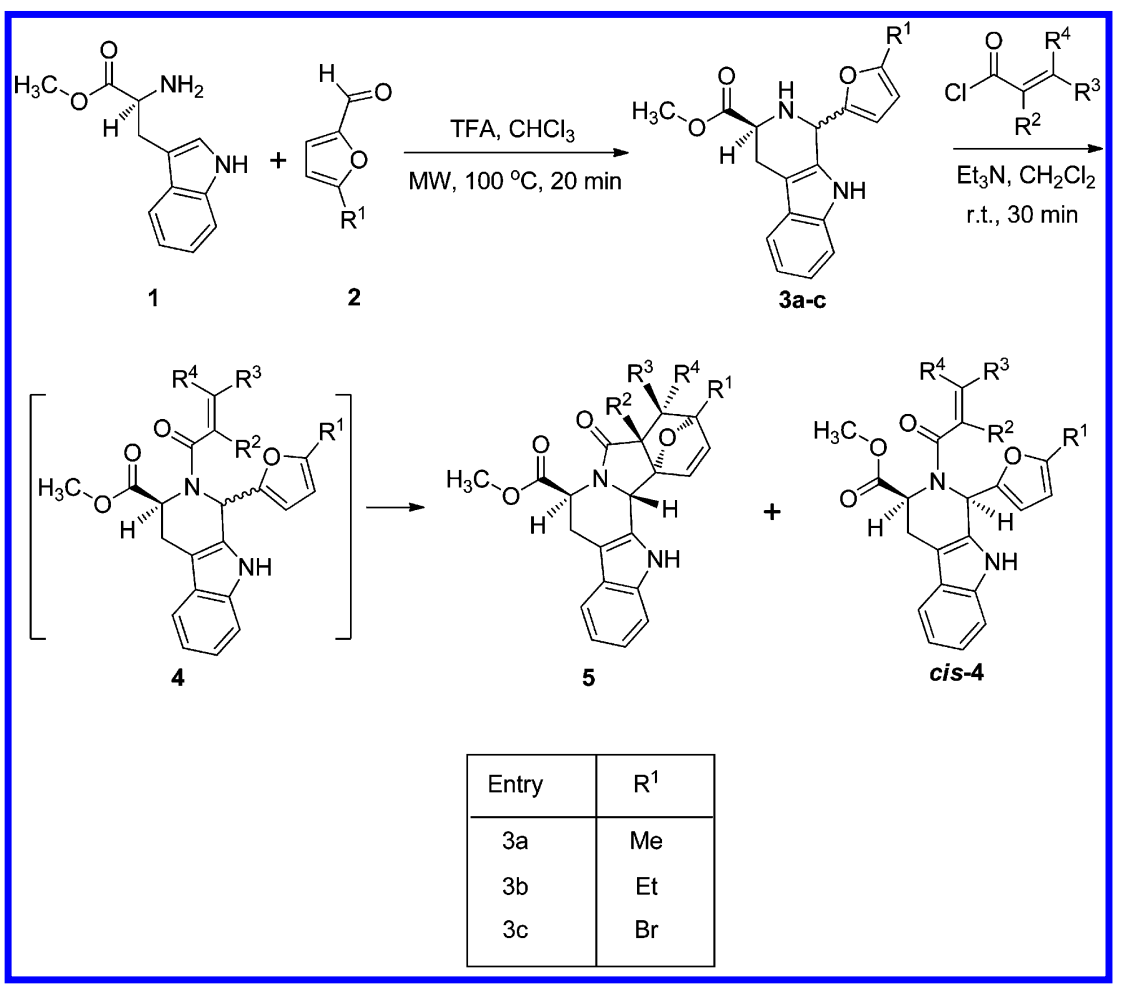


intramolecular Diels-Alder reaction in mild conditions provided the exo product of hexacyclic bridged indole alkaloids 5 (Scheme 1), while the cis isomer of $\mathrm{N}$-acylated product cis-4 remained unreacted and was separated from the mixture after reaction (the representative spectral data of cis-4 $\left(\mathrm{R}^{1}, \mathrm{R}^{2}, \mathrm{R}^{3}, \mathrm{R}^{4}\right.$ $=\mathrm{H})$ are provided in the Supporting Information).

The cycloaddition proceeds in a stereocontrolled fashion where an exo addition of the furan nucleus to the dienophile predominates. Although similar intramolecular Diels-Alder reactions of furan with $\alpha, \beta$-unsaturated amide are reported, ${ }^{14}$ here the fixed stereochemistry of the ester group at the C-3 position of $\beta$-carboline plays an important role in the stereochemical outcome of the present tandem IMDA reaction through chirality transfer. ${ }^{11,15}$ The putative explanation for diastereoselective Diels-Alder reaction is graphically depicted in Figure 3. The stereoselectivity mainly originates from the

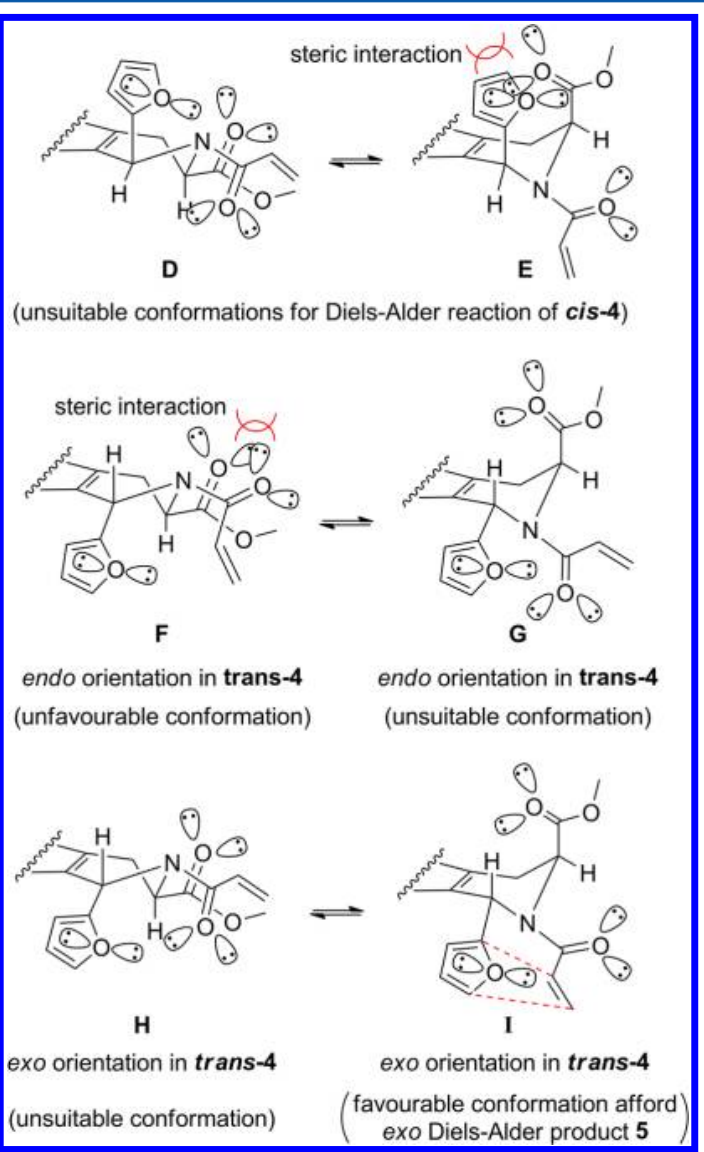

Figure 3. Putative reason for diastereoselective Diels-Alder cycloaddition.

steric repulsion and the orbital interactions. The acryloyl group on nitrogen lies anti to the $\mathrm{C}-3$ ester group due to lone pair steric interactions. The additional existence of $s$-cis and s-trans conformations in the acryloyl group due to the adjacent carbonyl group of the alkene functionality (dienophile) may affect the reactivity and stereoselectivity of the Diels-Alder reaction. The exo/endo selectivity involving s-cis and s-trans conformations was extensively studied, and it was found that the $s$-cis transition states are preferred over the corresponding $s$ trans transition states for both the exo and endo cyclization. ${ }^{16}$ Particularly in the acryloyl moiety, the s-cis conformer is more stable than the s-trans conformer and the exo approach is preferred over the endo approach. ${ }^{17}$ Moreover, the overall stereochemical outcome of the Diels-Alder reaction is envisaged through the orientation of the furan, ester, and amide moieties on the tetrahydropyridine ring in intermediate 4 as shown in Figure 3. The cis-4 isomer containing a pseudo1,3-diaxial alignment of the furan and ester moieties (E) possesses an unfavorable conformation due to 1,3-diaxial steric interaction between the ester carbonyl and the furan oxygen lone pairs, while another conformation of cis-4 with an equatorial orientation of the ester moiety (D) presumably involves an unfavorable alignment of the diene and dienophile motifs for Diels-Alder cycloaddition, resulting in an unreacted cis-4 product. Furthermore, four possible conformations are considered in the case of the trans-4 isomer. The endo orientation of the diene and dienophile moieties in the trans 4 transition state involves either an unfavorable conformation due to lone pair steric repulsions between the ester carbonyl and the furan oxygen $(F)$ or an unsuitable alignment of the diene and dienophile moieties (G) for endo Diels-Alder cycloaddition. Furthermore, the exo orientation of trans-4 containing equatorial ester and furan moieties acquires an unsuitable alignment for Diels-Alder reaction $(\mathbf{H})$. However, the exo orientation of trans-4 presumably involves a conformation where the furan oxygen lies anti to the ester group as well as to the amide group, with minimum steric repulsions prevailing between the lone pairs of the ester and amide carbonyl and the lone pairs of the furan oxygen (I). This conformation also acquires the most stable transition state and a suitable arrangement for intramolecular Diels-Alder reaction, resulting in stereoselective exo product 5. The stereochemical outcome of the tandem $\mathrm{N}$-acylation and intramolecular Diels-Alder reaction was later confirmed by single X-ray crystallographic studies. In this tandem approach of Pictet-Spengler reaction and acylation/intramolecular Diels-Alder reaction, five covalent bonds, four rings, and five stereocenters were generated with excellent stereoselectivity.

To generalize the present tandem $\mathrm{N}$-acylation and intramolecular Diels-Alder reaction, various substitutions at the 2position of furan were investigated along with the mono-, di-, and trisubstituted acryloyl chlorides as reactive dienophiles. It was observed that the reactivity of intramolecular Diels-Alder reaction was influenced by the electronic nature of the diene and dienophile and size of the substituents on the diene and dienophile. The Diels-Alder cycloaddition proceeded smoothly at room temperature with electron-rich dienes and electron-deficient dienophiles (Table 1, entries $\mathbf{5 a}, \mathbf{5 d}$, and $\mathbf{5 g}$ ), whereas slightly harsh conditions, such as reflux in dichloroethane, were required for substituted dienophiles because of the additional steric hindrance (Table 1 , entries $\mathbf{5 b}, \mathbf{5 c}, \mathbf{5 e}, \mathbf{5 f}, \mathbf{5 h}$, and $\mathbf{5 i}$ ), especially for a trisubstituted dienophile (Table 1, entry $\mathbf{5 j}$ ).

The stereochemical outcome of tandem acylation and IMDA reaction was initially determined by relative stereochemical studies through 1D NOE experiments of synthesized bridged hexacyclic alkaloid $\mathbf{5 h}$. The irradiation of the Ha proton did not show any enhancement in the $\mathrm{Hb}$ proton signal. In the same way, irradiation of the $\mathrm{Hb}$ proton did not show any enhancement in the Ha proton signal. These results evidently indicate the trans relationship between the stereochemically fixed $\mathrm{Ha}$ proton and $\mathrm{Hb}$ proton. However, irradiation of the $\mathrm{Hb}$ proton enhances the signals of the Hc proton by $1.10 \%$ as well as of methyl protons by $1.65 \%$, indicating the cis relationship between them (Figure 4). All these observations clearly verified the stereochemistry of the hexacyclic indole alkaloid. 
Table 1. Synthesis of Hexacyclic Indole Alkaloids $5^{a}$

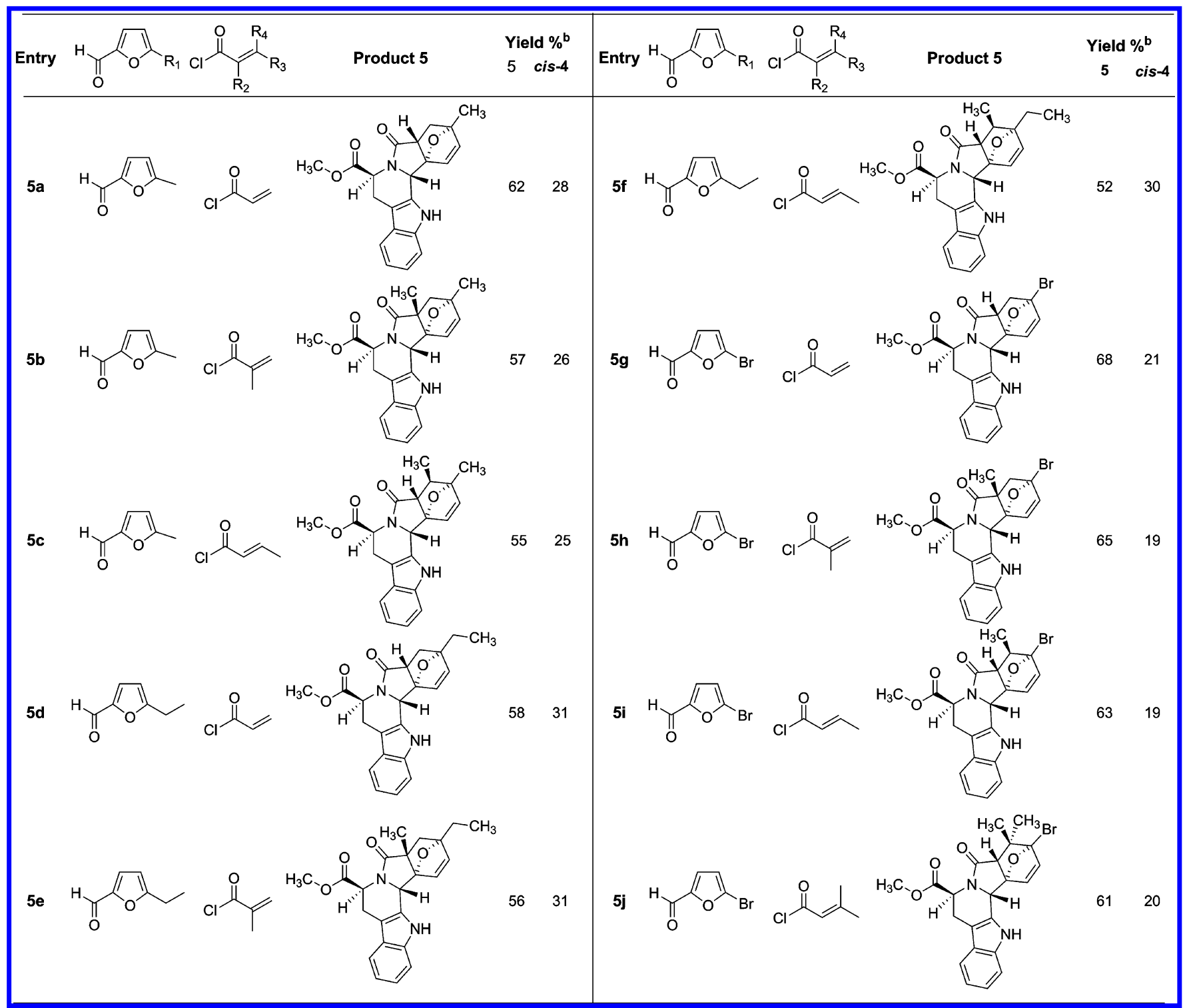

${ }^{a}$ Pictet-Spengler reaction was carried out in chloroform and $\mathrm{Et}_{3} \mathrm{~N}$ at reflux conditions or under microwave at $100{ }^{\circ} \mathrm{C}$ for $20 \mathrm{~min}$, and acylation/ IMDA reaction was carried out in dichloromethane and $\mathrm{NEt}_{3}$ at room temperature. ${ }^{b}$ Isolated yields after column purification.

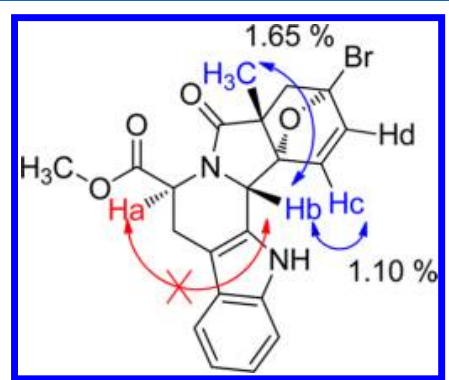

Figure 4. Key NOE enhancements of hexacyclic indole alkaloid $\mathbf{5 h}$.

To expand the scope of diversity, tandem $N$-acylation and IMDA reaction were also investigated for a pseudodienophile. Accordingly, 2 -substituted tetrahydro- $\beta$-carbolines 3 were treated with 2,3-dichloropropanoyl chloride in dichloromethane and triethylamine at room temperature. We found that the tandem reaction of $\mathrm{N}$-acylation followed by the intramolecular Diels-Alder-type reaction in mild conditions provided the similar exo product of hexacyclic bridged indole alkaloids 5, while the cis isomer remained unreacted (Scheme 2 ). Furthermore, the chloro group at the 2-position of 2,3dichloropropanoyl chloride introduced an additional significant quaternary center bearing a halide at the bridged multicyclic skeleton.

To increase the synthetic scope and utility of our tandem approach, the intramolecular Diels-Alder cyclization was also examined with the cyclic dienophile moiety. Accordingly, tetrahydro- $\beta$-carbolines 3 with methyl, ethyl, and bromo substitutions at the 5-position of the furan moiety were treated with maleic anhydride in ethylene dichloride, providing the cycloadducts 5n, 5o, and 5p upon refluxing for $5 \mathrm{~h}$ accompanied by the respective uncyclized cis-4 adducts (Scheme 3). The stereochemical outcome of the tandem $\mathrm{N}$ acylation and intramolecular Diels-Alder reaction is consistent with that of earlier studies. The cycloadducts $\mathbf{5 n}-\mathbf{p}$ contain an acid functionality, which allows further easy access to additional diversity in the skeleton. 
Scheme 2. Diels-Alder Reaction of 3 with 2,3Dichloropropanoyl Chloride ${ }^{a}$

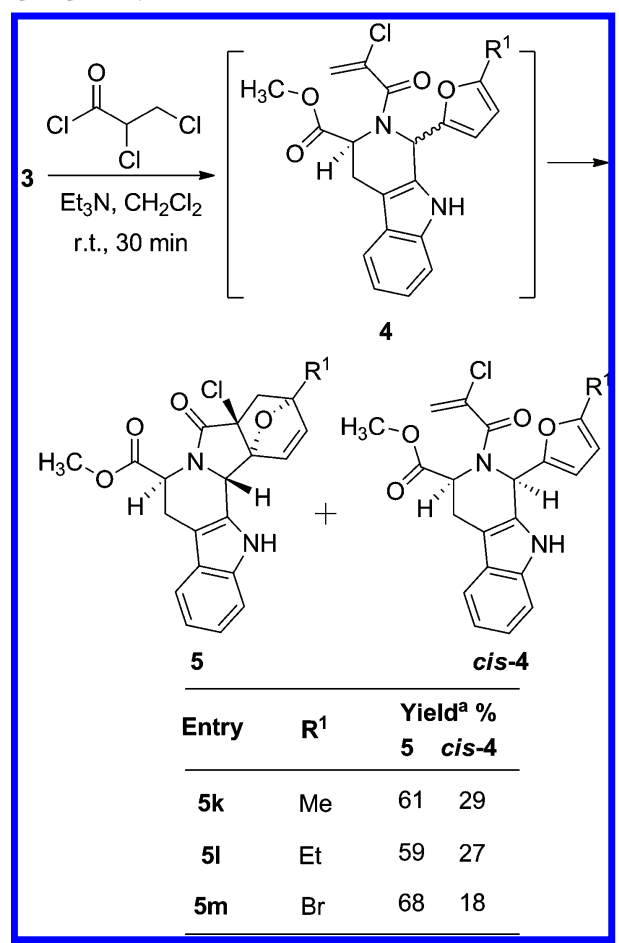

${ }^{a}$ Yields were determined on the basis of the weight of purified compounds.

Scheme 3. Diels-Alder Reaction of 3 with Maleic Anhydride ${ }^{a}$

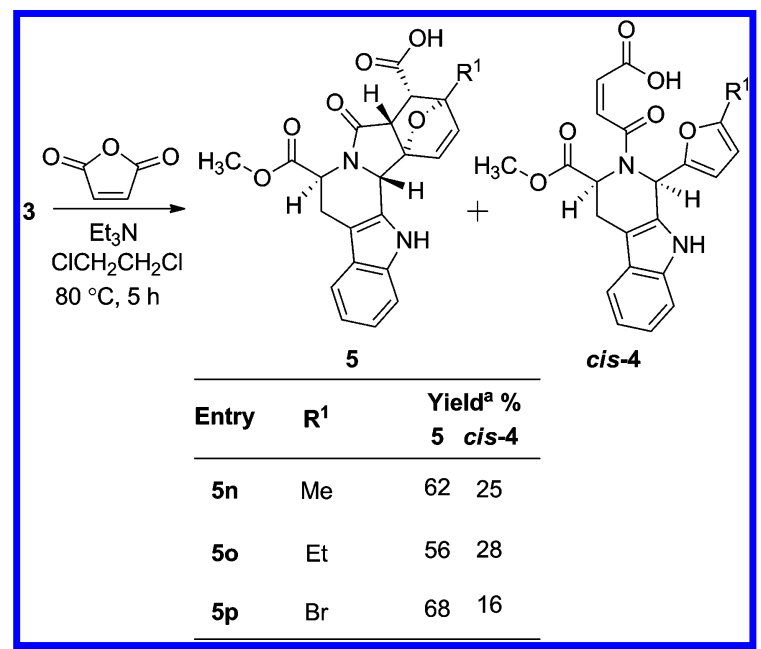

${ }^{a}$ Yields were determined on the basis of the weight of purified compounds.

At this stage, the stereochemical outcome of the tandem $\mathrm{N}$ acylation and IMDA reaction was unambiguously confirmed on the basis of X-ray crystallographic study of bridged hexacyclic indole alkaloid 5o. The ORTEP diagram of compound 5o is depicted in Figure 5 (crystallographic data provided in the Supporting Information, CCDC 829262). The hexacyclic ring system aligned in an " $\mathrm{L}$ " shape configuration, and the absolute configurations of $\mathrm{C}(10)$ and $\mathrm{C}(13)$ were $S$ and $R$, respectively. Furthermore, the proton on $\mathrm{C}(9)$ was trans to the proton on $\mathrm{C}(17)$ and cis to the proton on $\mathrm{C}(15)$.

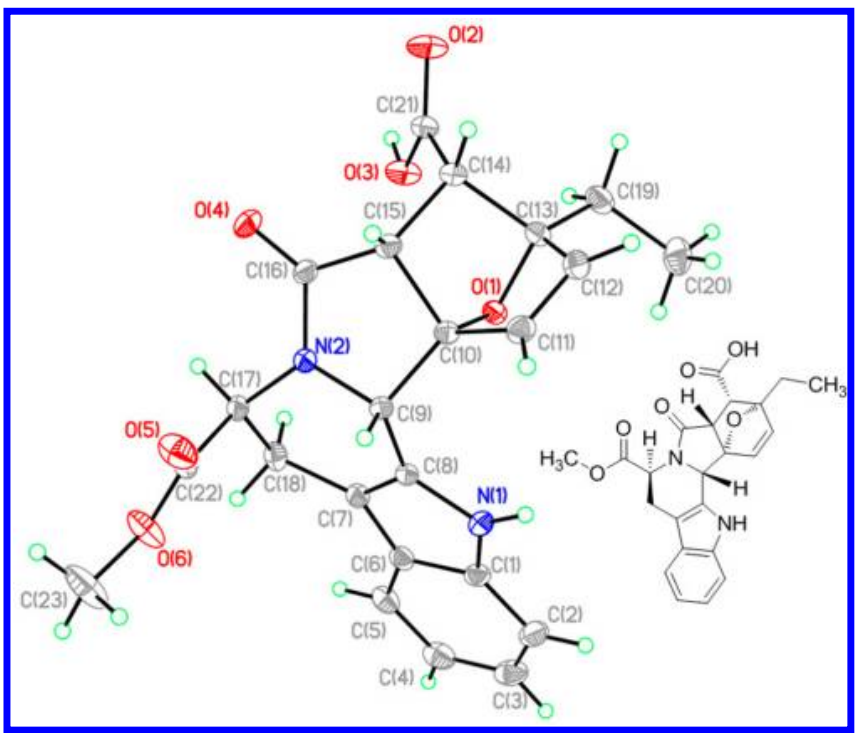

Figure 5. ORTEP diagram of compound 5o.

The intramolecular Diels-Alder reaction was also investigated for nonactivated dienophiles. Tetrahydro- $\beta$-carboline derivative 3 was reacted with allyl bromide and its derivatives and propargyl bromide in refluxing dichloromethane. The amide compound 6 was obtained after $12 \mathrm{~h}$ of reflux in dichloromethane in the presence of sodium hydride, a precursor for IMDA cycloaddition (Scheme 4). Only

Scheme 4. Diels-Alder Reaction of 3 with Nonactivated Dienophiles

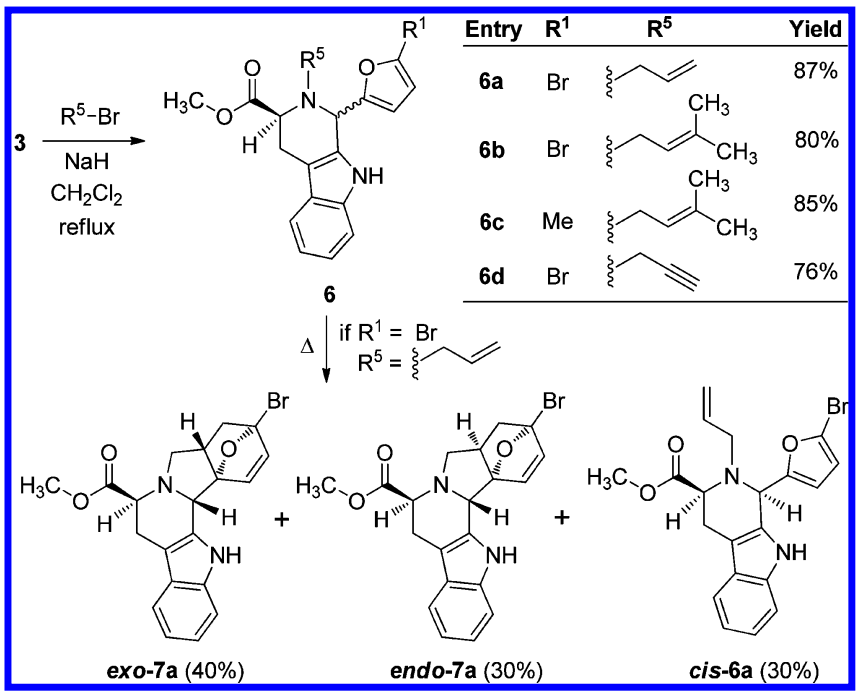

compound 6a was successively cyclized to furnish the hexacyclic diastereomers exo-7 (40\%) and endo-7 (30\%) accompanied by unreacted cis-6a isomer. The replacement of the carbonyl group from the dienophile by a methylene group resulting in the disappearance of the steric repulsions with the lone pair of the oxygen of the ester moiety led to the loss of stereoselectivity of the IMDA cyclization, consistent with the result observed with compounds 5 in Scheme 1. However, tetrahydro- $\beta$-carboline intermediates $6 \mathbf{b}, \mathbf{6 c}$, and $\mathbf{6 d}$ resisted further intramolecular Diels-Alder cycloaddition even under very harsh conditions, such as prolonged refluxing with toluene, xylene, or DMSO, because of the unfavorable electronic 
demand on dienophiles and the steric hindrance of the substituents.

Tandem $N$-acylation and intramolecular Diels-Alder reaction were also examined for thiophene as a diene unit. The thiophene-substituted tetrahydro- $\beta$-carboline, prepared from Pictet-Spengler cyclization of 1 with thiophene-2-carbaldehyde, was treated with acryloyl chloride in dichloromethane, furnishing the $\mathrm{N}$-acylated product. The intramolecular DielsAlder cycloaddition of the $\mathrm{N}$-acylated adduct did not proceed even under harsh conditions, such as a sealed vessel $\left(200{ }^{\circ} \mathrm{C}\right.$, $12 \mathrm{~h}$ ), microwave irradiation $\left(220^{\circ} \mathrm{C}, 0.5 \mathrm{~h}\right)$, and Lewis acid catalysis $\left(200{ }^{\circ} \mathrm{C}, 24 \mathrm{~h}\right)$ (detailed data provided in the Experimental Section). The higher resonance energy of thiophene $(121 \mathrm{~kJ} / \mathrm{mol})$ was probably the key factor leading to the inhibition of the intramolecular Diels-Alder cyclization.

After validation of the synthetic approach in solution, the synthesis of fused hexacyclic indole alkaloids was explored on a soluble polymer support as depicted in Scheme 5. Soluble-

Scheme 5. Synthesis of Hexacyclic Indole Alkaloids 5 on a Soluble Polymer Support

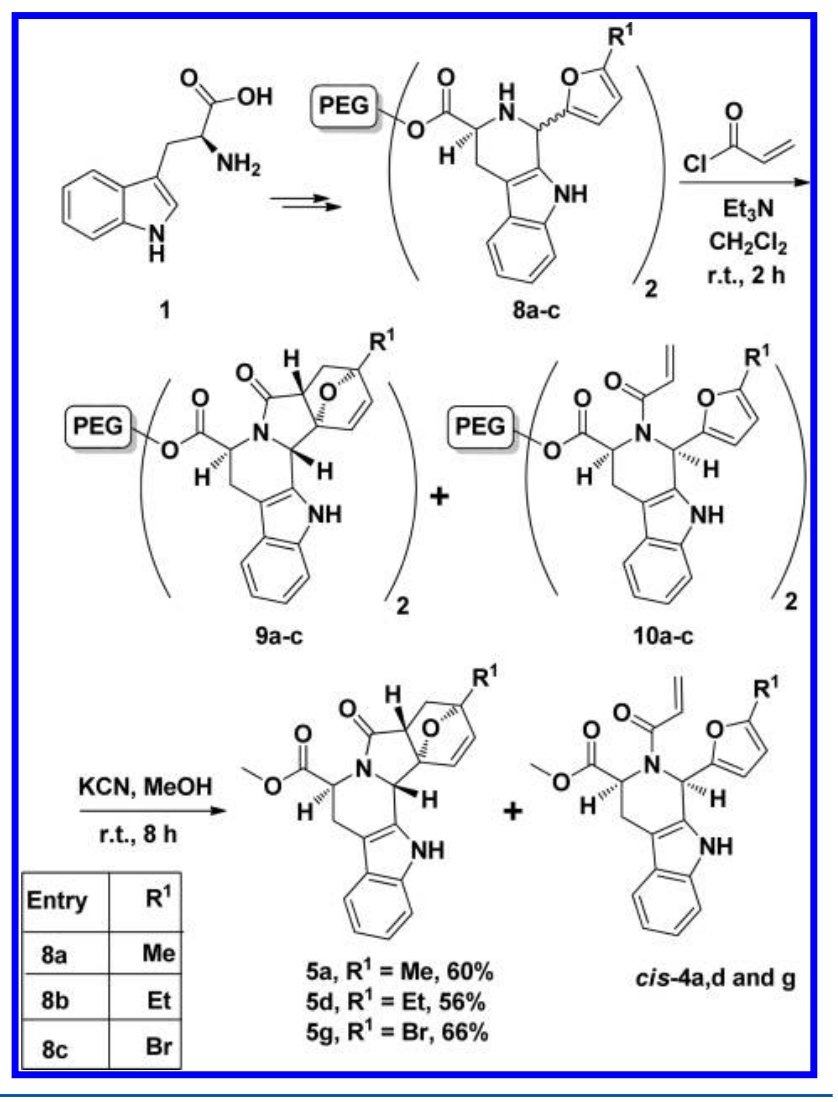

polymer-supported synthesis possesses many advantages over solid-phase synthesis, such as homogeneous reaction conditions, easy-to-monitor reaction progress by NMR, more normal reaction kinetics, and easier compound characterization, isolation, and purification through precipitation and filtration. ${ }^{18}$ In addition to bypassing chromatographic separation, the other advantages associated with the soluble polymer as a support have been very appealing for the green synthetic approach. Among the various soluble polymers, polyethylene glycol (PEG) has proven to be the most versatile and successful support to simplify and speed up the synthesis. ${ }^{19}$ The polyethylene glycol-supported tetrahydro- $\beta$-carboline conjugate
8 was initially prepared through three synthetic steps from tryptophan 1 following the procedures developed earlier. ${ }^{20}$ The polymer-supported compound $\mathbf{8}$ was treated with acryloyl chloride in dichloromethane and triethylamine. As expected, $\mathrm{N}$ acylation of $\mathbf{8}$ with an acryloyl chloride at room temperature afforded $\alpha, \beta$-unsaturated amide which spontaneously cyclized to form hexacyclic ring cycloadduct 9 upon stirring for $2 \mathrm{~h}$ at ambient temperature. Finally, the polymer support was cleaved in the solution of potassium cyanide in methanol to deliver 5 and uncyclized adduct cis-4 (Scheme 5). This soluble-polymersupported reaction strategy affords equivalent yields of $5(60 \%$, $56 \%$, and $66 \%$ for $5 \mathrm{a}, 5 \mathrm{~d}$, and $\mathbf{5 g}$, respectively) in comparison with the solution-phase synthesis $(62 \%, 58 \%$, and $68 \%$ for $5 a$, 5d, and 5g, respectively). This high-throughput polymersupported strategy has the ability to broaden the edges of the developed approach to deliver highly diversified libraries of polycyclic heterocycles.

\section{CONCLUSION}

In summary, Pictet-Spengler reaction and tandem acylation/ intramolecular Diels-Alder cyclization were systematically applied to develop an efficient diastereoselective synthesis of a bridged multicyclic skeleton with a tetrahydro- $\beta$-carboline motif. The tandem reaction was triggered by the $N$-acylation of tetrahydro- $\beta$-carboline, derived from Pictet-Spengler cyclization of L-tryptophan ester with furanaldehydes. Four new rings, five bonds, and five stereocenters were generated with excellent stereoselectivity. The diastereoselective formation of product was attributed to intramolecular chirality transfer through a chiral amino acid, which is reasonably explained by the most favorable conformation in the transition state of Dials-Alder cycloaddition. The stereochemical outcome of tandem acylation/IMDA reaction was determined by the relative stereochemical studies through $1 \mathrm{D}$ NOE experiments and unambiguously confirmed by the X-ray crystallographic studies. For the efficient generation of a polycyclic compound library, the developed synthetic strategy was also successfully explored on a soluble polymer support. Wider selection of commercially available amino acids, dienes, and dienophiles makes this a valuable approach to prepare highly diversified nitrogen heterocycles with a bridged multicyclic skeleton.

\section{EXPERIMENTAL SECTION}

General Methods. Dichloromethane was distilled from calcium hydride before use. All reactions were performed under an inert atmosphere with unpurified reagents and dry solvents. Analytical thinlayer chromatography (TLC) was performed using $0.25 \mathrm{~mm}$ silica gelcoated plates. Flash chromatography was performed using the indicated solvent and silica gel 60 (230-400 mesh). The microwave experiments were performed in a Biotage initiator under optimized reaction conditions of power and pressure. ${ }^{1} \mathrm{H}$ NMR $(300 \mathrm{MHz})$ and ${ }^{13} \mathrm{C}$ NMR (75 MHz) spectra were recorded on a $300 \mathrm{MHz}$ spectrometer. Chemical shifts are reported in parts per million (ppm) on the $\delta$ scale from an internal standard. Mass spectra were recorded on a time-of-flight mass spectrometer, samples being introduced by the infusion method by using the electrospray ionization method.

General Procedure for the Synthesis of Tetrahydro- $\beta$ carboline 3. Furaldehyde 2 ( $11.1 \mathrm{mmol}, 1.1$ equiv) and TFA (0.1 $\mathrm{mL}$ ) were added to a solution of L-tryptophan methyl ester (1) (2.2 g, $10.1 \mathrm{mmol}, 1.0$ equiv) in chloroform. The reaction mixture was refluxed for $6 \mathrm{~h}$ or reacted under microwave irradiation at $100{ }^{\circ} \mathrm{C}$ for $20 \mathrm{~min}$. The reaction mixture was quenched with water and extracted with dichloromethane. The combined extracts were concentrated and purified on column chromatography to give an inseparable 
diastereomeric mixture of tetrahydro- $\beta$-carboline 3 (cis:trans $=1: 1.15$ ) in $89 \%$ yield.

Data for methyl (3S)-1-(furan-2-yl)-2,3,4,4a,9,9a-tetrahydro$1 \mathrm{H}-\boldsymbol{\beta}$-carboline-3-carboxylate 3 (cis:trans $=1: 1.15$ ): ${ }^{1} \mathrm{H}$ NMR $\left(300 \mathrm{MHz} \mathrm{CDCl}_{3}\right) \delta 7.99(\mathrm{~s}, 1 \mathrm{H}), 7.93(\mathrm{~s}, 1 \mathrm{H}), 7.55(\mathrm{~d}, J=7.4 \mathrm{~Hz}$, $1 \mathrm{H}), 7.54$ (d, $J=7.4 \mathrm{~Hz}, 1 \mathrm{H}), 7.46$ (t, $J=1.3 \mathrm{~Hz}, 1 \mathrm{H}), 7.43$ (dd, $J=$ 1.6, $0.5 \mathrm{~Hz}, 1 \mathrm{H}), 7.33-7.28(\mathrm{~m}, 2 \mathrm{H}), 7.21-7.11(\mathrm{~m}, 4 \mathrm{H}), 6.41(\mathrm{~d}, J=$ $1.3 \mathrm{~Hz}, 1 \mathrm{H}), 6.32(\mathrm{dd}, J=3.2,1.9 \mathrm{~Hz}, 1 \mathrm{H}), 6.11(\mathrm{~d}, J=3.2 \mathrm{~Hz}, 1 \mathrm{H})$, $5.46(\mathrm{~s}, 1 \mathrm{H}), 5.44(\mathrm{t}, J=2.2 \mathrm{~Hz}, 1 \mathrm{H}), 3.99(\mathrm{dd}, J=9.0,4.8 \mathrm{~Hz}, 1 \mathrm{H})$, $3.96(\mathrm{dd}, J=11.0,4.4 \mathrm{~Hz}, 1 \mathrm{H}), 3.84(\mathrm{~s}, 3 \mathrm{H}), 3.79$ (s, $3 \mathrm{H}), 3.22$ (dd, $J$ $=15.3,4.6 \mathrm{~Hz}, 1 \mathrm{H}), 3.21(\mathrm{dd}, J=15.3,4.6 \mathrm{~Hz}, 1 \mathrm{H}), 3.04-2.94(\mathrm{~m}$, $2 \mathrm{H}) ;{ }^{13} \mathrm{C} \mathrm{NMR}\left(75 \mathrm{MHz}, \mathrm{CDCl}_{3}\right) \delta 143.2,143.1,136.5,136.4,132.3$, $131.3,127.4,127.2,122.6,122.6,120.1,120.0,118.7,118.7,111.4$, $111.4,110.9,110.6,109.2,109.1,108.2,108.1,56.9,52.8,52.7,52.6$, 52.1, 49.5; ESI-MS $m / z 297.2\left(\mathrm{M}+\mathrm{H}^{+}\right)$.

General Procedure for the Synthesis of Multicyclic Indole Alkaloids $5 \mathbf{a}-\mathbf{m}$. Acryloyl chloride (0.9 mmol, 1.5 equiv) and triethylamine $(3.0 \mathrm{mmol}, 5.0$ equiv) were added to the solution of compound 3 ( $0.2 \mathrm{~g}, 0.6 \mathrm{mmol}, 1.0$ equiv) in dichloromethane (20 $\mathrm{mL})$, and the reaction mixture was stirred at room temperature for 30 min. The reaction was quenched by ice-water and extracted with dichloromethane. The extracts were concentrated under reduced pressure, and the crude product was then purified by silica gel column chromatography using a 2:1 mixture of hexane and ethyl acetate as the eluent to afford the corresponding products 5 a $(0.145 \mathrm{~g}, 68 \%$ yield) and cis-4a $(0.065 \mathrm{~g}, 28 \%$ yield).

All other derivatives, $\mathbf{5 b}-\mathbf{m}$ and cis $\mathbf{4} \mathbf{b}-\mathbf{m}$, were synthesized by the same above-mentioned procedure.

Data for methyl $(3 S, 4 \mathrm{a} R, 7 S, 13 \mathrm{bS}, 13 \mathrm{cS})-3$-methyl-5-oxo$3,4,4 a, 5,7,8,13,13 \mathrm{~b}$-octahydro-3, $13 \mathrm{c}$-epoxybenzo[ 1,2$]$ indolizino[8,7-b] indole-7-carboxylate (5a): ${ }^{1} \mathrm{H}$ NMR $(300 \mathrm{MHz}$, $\left.\mathrm{CDCl}_{3}\right) \delta 8.57(\mathrm{~s}, 1 \mathrm{H}), 7.49(\mathrm{~d}, J=7.0 \mathrm{~Hz}, 1 \mathrm{H}), 7.28(\mathrm{~d}, J=7.3 \mathrm{~Hz}$, $1 \mathrm{H}), 7.18-7.09(\mathrm{~m}, 2 \mathrm{H}), 6.63(\mathrm{~d}, J=5.6 \mathrm{~Hz}, 1 \mathrm{H}), 6.33(\mathrm{~d}, J=5.6 \mathrm{~Hz}$, $1 \mathrm{H}), 5.76(\mathrm{~s}, 1 \mathrm{H}), 5.47(\mathrm{~d}, J=6.6 \mathrm{~Hz}, 1 \mathrm{H}), 3.69(\mathrm{~s}, 3 \mathrm{H}), 3.44(\mathrm{~d}, J=$ $15.8 \mathrm{~Hz}, 1 \mathrm{H}), 3.19$ (ddd, $J=15.8,7.2,2.1 \mathrm{~Hz}, 1 \mathrm{H}), 2.83$ (dd, $J=8.7$, $3.5 \mathrm{~Hz}, 1 \mathrm{H}), 1.95$ (dd, $J=8.7,3.5 \mathrm{~Hz}, 1 \mathrm{H}), 1.71(\mathrm{dd}, J=11.7,8.7 \mathrm{~Hz}$, 1H), 1.52 (s, 3H); ${ }^{13} \mathrm{C} \mathrm{NMR}\left(75 \mathrm{MHz} \mathrm{CDCl}_{3}\right) \delta 174.0,172.1,142.2$, 137.2, 133.3, 128.0, 127.1, 122.6, 119.9, 118.8, 111.6, 107.6, 91.2, 87.7, 54.7, 53.1, 52.0, 49.8, 34.6, 24.0, 14.6; IR ( $\mathrm{cm}^{-1}$, neat) 1743, 1681; ESI-MS $m / z 387\left(\mathrm{M}+\mathrm{Na}^{+}\right)$; HRMS calcd for $\mathrm{C}_{21} \mathrm{H}_{20} \mathrm{~N}_{2} \mathrm{O}_{4} \mathrm{Na} m / z$ 387.1321, found 387.1324; $[\alpha]_{\mathrm{D}}^{28}=109.2(c=0.13)$.

Data for methyl $(3 S, 4 a R, 7 S, 13 \mathrm{bS}, 13 \mathrm{cS})-3,4 \mathrm{a}$-dimethyl-5-oxo$3,4,4 a, 5,7,8,13,13 \mathrm{~b}$-octahydro-3, $13 \mathrm{c}$-epoxybenzo[ 1,2$]$ indolizino[8,7-b]indole-7-carboxylate (5b): ${ }^{1} \mathrm{H}$ NMR $(300 \mathrm{MHz}$, $\left.\mathrm{CDCl}_{3}\right) \delta 8.03(\mathrm{~s}, 1 \mathrm{H}), 7.50(\mathrm{~d}, J=7.5 \mathrm{~Hz}, 1 \mathrm{H}), 7.31(\mathrm{~d}, J=7.5 \mathrm{~Hz}$, $1 \mathrm{H}), 7.21-7.08(\mathrm{~m}, 2 \mathrm{H}), 6.65(\mathrm{~d}, J=5.6 \mathrm{~Hz}, 1 \mathrm{H}), 6.43(\mathrm{~d}, J=5.6 \mathrm{~Hz}$, $1 \mathrm{H}), 5.66(\mathrm{~s}, 1 \mathrm{H}), 5.42(\mathrm{~d}, J=6.7 \mathrm{~Hz}, 1 \mathrm{H}), 3.69(\mathrm{~s}, 3 \mathrm{H}), 3.43(\mathrm{~d}, J=$ $15.8 \mathrm{~Hz}, 1 \mathrm{H}), 3.20$ (ddd, $J=15.8,7.4,2.1 \mathrm{~Hz}, 1 \mathrm{H}), 2.23(\mathrm{~d}, J=11.8$ $\mathrm{Hz}, 1 \mathrm{H}), 1.48$ (s, 3H), 1.25 (d, $J=11.8 \mathrm{~Hz}, 1 \mathrm{H}), 1.23(\mathrm{~s}, 3 \mathrm{H}) ;{ }^{13} \mathrm{C}$ NMR $\left(75 \mathrm{MHz}, \mathrm{CDCl}_{3}\right) \delta 177.4,172.1,143.0,137.2,131.4,128.0$, $127.3,122.7,120.1,118.9,111.6,108.0,92.9,87.4,57.1,53.1,53.0$, 49.3, 42.5, 23.8, 20.5, 19.3; IR ( $\mathrm{cm}^{-1}$, neat) 1741, 1671; ESI-MS $\mathrm{m} / z$ $401\left(\mathrm{M}+\mathrm{Na}^{+}\right)$; HRMS calcd for $\mathrm{C}_{22} \mathrm{H}_{22} \mathrm{~N}_{2} \mathrm{O}_{4} \mathrm{Na} m / z 401.1477$, found 401.1476; $[\alpha]_{\mathrm{D}}^{30}=52.5(c=0.18)$.

Data for methyl $(3 R, 4 R, 4 \mathrm{a} R, 7 S, 13 \mathrm{bS}, 13 \mathrm{c} S)$-3,4-dimethyl-5oxo-3,4,4a,5,7,8,13,13b-octahydro-3,13c-epoxybenzo[1,2]indolizino[8,7-b]indole-7-carboxylate (5c): ${ }^{1} \mathrm{H}$ NMR (300 MHz, $\left.\mathrm{CDCl}_{3}\right) \delta 7.85(\mathrm{~s}, 1 \mathrm{H}), 7.50(\mathrm{~d}, J=7.6 \mathrm{~Hz}, 1 \mathrm{H}), 7.34(\mathrm{~d}, J=8.0 \mathrm{~Hz}$, $1 \mathrm{H}), 7.22-7.09(\mathrm{~m}, 2 \mathrm{H}), 6.75(\mathrm{~d}, J=5.7 \mathrm{~Hz}, 1 \mathrm{H}), 6.36(\mathrm{~d}, J=5.7 \mathrm{~Hz}$, $1 \mathrm{H}), 5.69(\mathrm{~s}, 1 \mathrm{H}), 5.42(\mathrm{~d}, J=6.6 \mathrm{~Hz}, 1 \mathrm{H}), 3.69(\mathrm{~s}, 3 \mathrm{H}), 3.41(\mathrm{~d}, J=$ $15.8 \mathrm{~Hz}, 1 \mathrm{H}), 3.19$ (ddd, $J=15.8,7.3,2.2 \mathrm{~Hz}, 1 \mathrm{H}), 2.41(\mathrm{~d}, J=3.8 \mathrm{~Hz}$, $1 \mathrm{H}), 2.25$ (m, 1H), 1.48 (s, 3H), 1.02 (d, $J=7.1 \mathrm{~Hz}, 3 \mathrm{H}) ;{ }^{13} \mathrm{C}$ NMR $\left(75 \mathrm{MHz} \mathrm{CDCl}_{3}\right) \delta 173.5,172.0,141.2,137.1,133.9,128.0,127.2$, $122.8,120.2,118.9,111.6,108.1,90.5,90.4,59.2,54.4,53.0,49.5,42.6$, 23.9, 17.6, 17.4; IR ( $\mathrm{cm}^{-1}$, neat) 1741, 1677; ESI-MS $\mathrm{m} / z 401(\mathrm{M}+$ $\mathrm{Na}^{+}$); HRMS calcd for $\mathrm{C}_{22} \mathrm{H}_{22} \mathrm{~N}_{2} \mathrm{O}_{4} \mathrm{Na} m / z$ 401.1477, found 401.1475; $[\alpha]_{\mathrm{D}}^{31}=92.6(c=0.8)$.

Data for methyl $(3 S, 4 a R, 7 S, 13 \mathrm{bS}, 13 \mathrm{cS})$-3-ethyl-5-oxo$3,4,4 a, 5,7,8,13,13 \mathrm{~b}$-octahydro-3,13c-epoxybenzo[1,2]indolizino[8,7-b]indole-7-carboxylate (5d): ${ }^{1} \mathrm{H}$ NMR $(300 \mathrm{MHz}$, $\left.\mathrm{CDCl}_{3}\right) \delta 8.03(\mathrm{~s}, 1 \mathrm{H}), 7.50(\mathrm{~d}, J=7.5 \mathrm{~Hz}, 1 \mathrm{H}), 7.33(\mathrm{~d}, J=7.5 \mathrm{~Hz}$,
$1 \mathrm{H}), 7.21-7.09(\mathrm{~m}, 2 \mathrm{H}), 6.66(\mathrm{~d}, J=5.8 \mathrm{~Hz}, 1 \mathrm{H}), 6.44(\mathrm{~d}, J=5.8 \mathrm{~Hz}$, $1 \mathrm{H}), 5.76(\mathrm{~s}, 1 \mathrm{H}), 5.44(\mathrm{~d}, J=6.7 \mathrm{~Hz}, 1 \mathrm{H}), 3.70(\mathrm{~s}, 3 \mathrm{H}), 3.42$ (d, J = $15.8 \mathrm{~Hz}, 1 \mathrm{H}), 3.19$ (ddd, $J=15.8,7.3,2.2 \mathrm{~Hz}, 1 \mathrm{H}), 2.82(\mathrm{~m}, 1 \mathrm{H}), 1.95$ (dd, $J=11.8,3.5 \mathrm{~Hz}, 1 \mathrm{H}), 1.85(\mathrm{q}, J=7.6 \mathrm{~Hz}, 2 \mathrm{H}), 1.69(\mathrm{~m}, 1 \mathrm{H}), 0.95$ $(\mathrm{t}, J=7.6 \mathrm{~Hz}, 3 \mathrm{H}) ;{ }^{13} \mathrm{C} \mathrm{NMR}\left(75 \mathrm{MHz} \mathrm{CDCl}_{3}\right) \delta 173.8,172.1,141.0$, 137.2 , 133.1, 128.1, 127.2, 122.7, 120.1, 118.9, 111.6, 107.9, 91.8, 90.7, 54.6, 53.0, 51.5, 49.6, 32.4, 26.0, 23.9, 9.7; IR ( $\mathrm{cm}^{-1}$, neat) 1741, 1673; ESI-MS $m / z 401\left(\mathrm{M}+\mathrm{Na}^{+}\right)$; HRMS calcd for $\mathrm{C}_{22} \mathrm{H}_{22} \mathrm{~N}_{2} \mathrm{O}_{4} \mathrm{Na} m / z$ 401.1477, found 401.1480; $[\alpha]_{\mathrm{D}}^{30}=31.0(c=0.24)$.

Data for methyl $(3 S, 4 \mathrm{a} R, 7 S, 13 \mathrm{bS}, 13 \mathrm{cS})$-3-ethyl-4a-methyl-5oxo-3,4,4a,5,7,8,13,13b-octahydro-3,13c-epoxybenzo[1,2]indolizino[8,7-b]indole-7-carboxylate (5e): ${ }^{1} \mathrm{H}$ NMR (300 MHz, $\left.\mathrm{CDCl}_{3}\right) \delta 8.21(\mathrm{~s}, 1 \mathrm{H}), 7.48(\mathrm{~d}, J=9.1 \mathrm{~Hz}, 1 \mathrm{H}), 7.28(\mathrm{~m}, 1 \mathrm{H}), 7.17-$ $7.06(\mathrm{~m}, 2 \mathrm{H}), 6.64(\mathrm{~d}, J=5.8 \mathrm{~Hz}, 1 \mathrm{H}), 6.48(\mathrm{~d}, J=5.8 \mathrm{~Hz}, 1 \mathrm{H}), 5.64$ $(\mathrm{s}, 1 \mathrm{H}), 5.41(\mathrm{~d}, J=6.7 \mathrm{~Hz}, 1 \mathrm{H}), 3.67(\mathrm{~s}, 3 \mathrm{H}), 3.41(\mathrm{~d}, J=15.8 \mathrm{~Hz}$, $1 \mathrm{H}), 3.18$ (ddd, $J=15.8,7.3,2.1 \mathrm{~Hz}, 1 \mathrm{H}), 2.21(\mathrm{~d}, J=11.7 \mathrm{~Hz}, 1 \mathrm{H})$, $1.74(\mathrm{q}, J=7.5 \mathrm{~Hz}, 2 \mathrm{H}), 1.25-1.20(\mathrm{~m}, 4 \mathrm{H}), 0.90(\mathrm{t}, J=7.5 \mathrm{~Hz}, 3 \mathrm{H})$; ${ }^{13} \mathrm{C} \mathrm{NMR}\left(75 \mathrm{MHz} \mathrm{CDCl}_{3}\right) \delta 177.6,172.1,141.2,137.2,131.6,128.1$, 127.2 , 122.6, 120.0, 118.8, 111.6, 107.9, 92.7, 91.4, 56.7, 53.2, 53.2, 55.0, 49.4, 26.1, 23.9, 20.5, 9.6; IR ( $\mathrm{cm}^{-1}$, neat) 1743, 1677; ESI-MS $m / z 415\left(\mathrm{M}+\mathrm{Na}^{+}\right)$; HRMS calcd for $\mathrm{C}_{23} \mathrm{H}_{24} \mathrm{~N}_{2} \mathrm{O}_{4} \mathrm{Na} m / z$ 415.1634, found 415.1631; $[\alpha]_{\mathrm{D}}^{30}=40.9(c=0.16)$.

Data for methyl $(3 R, 4 R, 4 \mathrm{a} R, 7 S, 13 \mathrm{bS}, 13 \mathrm{cS})$-3-ethyl-4-methyl5-oxo-3,4,4a,5,7,8,13,13b-octahydro-3,13c-epoxybenzo[1,2]indolizino[8,7-b]indole-7-carboxylate (5f): ${ }^{1} \mathrm{H}$ NMR $(300 \mathrm{MHz}$, $\left.\mathrm{CDCl}_{3}\right) \delta 8.38(\mathrm{~s}, 1 \mathrm{H}), 7.50(\mathrm{~d}, J=7.3 \mathrm{~Hz}, 1 \mathrm{H}), 7.31(\mathrm{~d}, J=7.3 \mathrm{~Hz}$, $1 \mathrm{H}), 7.20-7.08(\mathrm{~m}, 2 \mathrm{H}), 6.72(\mathrm{~d}, J=5.7 \mathrm{~Hz}, 1 \mathrm{H}), 6.35(\mathrm{~d}, J=5.7 \mathrm{~Hz}$, $1 \mathrm{H}), 5.70(\mathrm{~s}, 1 \mathrm{H}), 5.44(\mathrm{~d}, J=7.0 \mathrm{~Hz}, 1 \mathrm{H}), 3.68(\mathrm{~s}, 3 \mathrm{H}), 3.42$ (d, $J=$ $15.8 \mathrm{~Hz}, 1 \mathrm{H}), 3.19$ (ddd, $J=15.8,7.3,2.0 \mathrm{~Hz}, 1 \mathrm{H}), 2.38(\mathrm{~d}, J=3.8 \mathrm{~Hz}$, $1 \mathrm{H}), 2.31(\mathrm{~m}, 1 \mathrm{H}), 1.93(\mathrm{~m}, 1 \mathrm{H}), 1.73(\mathrm{~m}, 1 \mathrm{H}), 0.97(\mathrm{~d}, J=7.0 \mathrm{~Hz}$, $3 \mathrm{H}), 0.88(\mathrm{t}, J=7.5 \mathrm{~Hz}, 3 \mathrm{H}) ;{ }^{13} \mathrm{C} \mathrm{NMR}\left(75 \mathrm{MHz}, \mathrm{CDCl}_{3}\right) \delta 173.9$, $172.1,139.5,137.2,134.2,128.1,127.2,122.6,119.9,118.8,111.6$, 107.7, 94.2, 90.4, 59.3, 54.6, 53.0, 49.6, 40.6, 24.2, 23.9, 17.6, 9.4; IR $\left(\mathrm{cm}^{-1}\right.$, neat) 1747,1673 ; ESI-MS $m / z 415\left(\mathrm{M}+\mathrm{Na}^{+}\right)$; HRMS calcd for $\mathrm{C}_{23} \mathrm{H}_{24} \mathrm{~N}_{2} \mathrm{O}_{4} \mathrm{Na} m / z$ 415.1634, found 415.1632; $[\alpha]_{\mathrm{D}}^{29}=96.6$ (c $0.31)$.

Data for methyl $(3 R, 4 \mathrm{a} R, 7 S, 13 \mathrm{bS}, 13 \mathrm{c} S)$-3-bromo-5-oxo$3,4,4 a, 5,7,8,13,13 \mathrm{~b}$ - octahydro-3,13c-epoxybenzo[1,2]indolizino $[8,7-b]$ indole-7-carboxylate $(\mathbf{5 g}):{ }^{1} \mathrm{H}$ NMR (300 $\left.\mathrm{MHz} \mathrm{CDCl}_{3}\right) \delta 7.96(\mathrm{~s}, 1 \mathrm{H}), 7.51(\mathrm{~d}, J=7.7 \mathrm{~Hz}, 1 \mathrm{H}), 7.35$ (d, $J=$ $8.0 \mathrm{~Hz}, 1 \mathrm{H}), 7.25-7.11(\mathrm{~m}, 2 \mathrm{H}), 6.72(\mathrm{~d}, J=5.6 \mathrm{~Hz}, 1 \mathrm{H}), 6.59$ (d, J = $5.6 \mathrm{~Hz}, 1 \mathrm{H}), 5.82$ (s, 1H), $5.44(\mathrm{~d}, J=6.5 \mathrm{~Hz}, 1 \mathrm{H}), 3.70(\mathrm{~s}, 3 \mathrm{H}), 3.43$ (d, $J=15.9 \mathrm{~Hz}, 1 \mathrm{H}$ ), 3.22 (ddd, $J=15.9,7.3,2.2 \mathrm{~Hz}, 1 \mathrm{H}$ ), 2.93 (dd, $J$ $=8.7,3.6 \mathrm{~Hz}, 1 \mathrm{H}), 2.58(\mathrm{dd}, J=12.1,3.6 \mathrm{~Hz}, 1 \mathrm{H}), 2.27(\mathrm{~d}, J=12.1$, $8.7 \mathrm{~Hz}, 1 \mathrm{H}) ;{ }^{13} \mathrm{C} \mathrm{NMR}\left(75 \mathrm{MHz}, \mathrm{CDCl}_{3}\right) \delta 171.8,171.7,143.4,137.2$, $133.4,127.1,126.6,123.1,120.3,119.0,111.7,108.6,90.3,88.9,54.3$, 53.1, 51.6, 49.8, 39.4, 23.9; IR ( $\mathrm{cm}^{-1}$, neat) 1739, 1679; ESI-MS $\mathrm{m} / z$ $451\left(\mathrm{M}+\mathrm{Na}^{+}\right)$; HRMS calcd for $\mathrm{C}_{20} \mathrm{H}_{17} \mathrm{BrN}_{2} \mathrm{O}_{4} \mathrm{Na} m / z$ 451.0274, found 451.0276; $[\alpha]_{\mathrm{D}}^{29}=90.6(c=0.13)$.

Data for methyl $(3 R, 4 \mathrm{a} R, 7 S, 13 \mathrm{bS}, 13 \mathrm{cS})$-3-bromo-4a-methyl5-oxo-3,4,4a,5,7,8,13,13b-octahydro-3,13c-epoxybenzo[1,2]indolizino[8,7-b]indole-7-carboxylate (5h): ${ }^{1} \mathrm{H}$ NMR $(300 \mathrm{MHz}$, $\left.\mathrm{CDCl}_{3}\right) \delta 8.12(\mathrm{~s}, 1 \mathrm{H}), 7.51(\mathrm{~d}, J=7.6 \mathrm{~Hz}, 1 \mathrm{H}), 7.33(\mathrm{~d}, J=7.6 \mathrm{~Hz}$, $1 \mathrm{H}), 7.22-7.10(\mathrm{~m}, 2 \mathrm{H}), 6.69(\mathrm{~d}, J=5.6 \mathrm{~Hz}, 1 \mathrm{H}), 6.63(\mathrm{~d}, J=5.6 \mathrm{~Hz}$, $1 \mathrm{H}), 5.74(\mathrm{~s}, 1 \mathrm{H}), 5.42$ (d, $J=6.8 \mathrm{~Hz}, 1 \mathrm{H}), 3.69(\mathrm{~s}, 3 \mathrm{H}), 3.43$ (d, $J=$ $15.9 \mathrm{~Hz}, 1 \mathrm{H}$ ), 3.24 (ddd, $J=15.9,7.3,2.1 \mathrm{~Hz}, 1 \mathrm{H}$ ), 2.82 (d, $J=12.0$ $\mathrm{Hz}, 1 \mathrm{H}), 1.82$ (d, $J=12.0 \mathrm{~Hz}, 1 \mathrm{H}), 1.27(\mathrm{~s}, 3 \mathrm{H}) ;{ }^{13} \mathrm{C} \mathrm{NMR}(75 \mathrm{MHz}$, $\left.\mathrm{CDCl}_{3}\right) \delta 175.6,171.9,143.4,137.3,132.1,127.1,126.6,123.0,120.2$, $118.9,111.7,108.5,92.4,89.0,57.3,53.1,52.9,49.5,47.1,23.9,20.0$; IR $\left(\mathrm{cm}^{-1}\right.$, neat) 1725, 1702; ESI-MS $m / z 465\left(\mathrm{M}+\mathrm{Na}^{+}\right)$; HRMS calcd for $\mathrm{C}_{21} \mathrm{H}_{19} \mathrm{BrN}_{2} \mathrm{O}_{4} \mathrm{Na} m / z$ 465.0426, found 465.0430; $[\alpha]_{\mathrm{D}}^{30}=$ $117.9(c=0.20)$.

Data for methyl $(3 S, 4 R, 4 \mathrm{a} R, 7 \mathrm{~S}, 13 \mathrm{bS}, 13 \mathrm{cS})$-3-bromo-4-methyl-5-oxo-3,4,4a,5,7,8,13,13b-octahydro-3,13c-epoxybenzo[1,2]indolizino[8,7-b]indole-7-carboxylate (5i): ${ }^{1} \mathrm{H}$ NMR (300 $\mathrm{MHz}, d$-DMSO) $\delta 11.06(\mathrm{~s}, 1 \mathrm{H}), 7.45(\mathrm{~d}, J=7.7 \mathrm{~Hz}, 1 \mathrm{H}), 7.35$ (d, $J=$ $8.0 \mathrm{~Hz}, 1 \mathrm{H}), 7.14-6.97(\mathrm{~m}, 2 \mathrm{H}), 7.04$ (d, $J=5.7 \mathrm{~Hz}, 1 \mathrm{H}), 6.60$ (d, $J=$ $5.7 \mathrm{~Hz}, 1 \mathrm{H}), 5.77$ (s, $1 \mathrm{H}), 5.30(\mathrm{~d}, J=6.3 \mathrm{~Hz}, 1 \mathrm{H}), 3.61(\mathrm{~s}, 3 \mathrm{H}), 3.30$ (d, $J=15.8 \mathrm{~Hz}, 1 \mathrm{H}), 2.93(\mathrm{ddd}, J=15.8,7.0,1.8 \mathrm{~Hz}, 1 \mathrm{H}), 2.72$ (d, $J=$ 3.7 Hz, 1H), 2.44 (dd, $J=7.0,3.7 \mathrm{~Hz}, 1 \mathrm{H}), 1.02(\mathrm{~d}, J=7.0 \mathrm{~Hz}, 3 \mathrm{H}$ ); ${ }^{13} \mathrm{C}$ NMR (75 MHz, d-DMSO) $\delta 172.1,171.8,138.6,137.4,137.0$ 
$127.8,126.9,122.5,119.7,118.8,112.3,106.5,95.5,91.6,57.5,54.3$, 53.4, 49.8, 48.0, 24.1, 16.9; IR ( $\mathrm{cm}^{-1}$, neat) 1735, 1673; ESI-MS $\mathrm{m} / z$ $465\left(\mathrm{M}+\mathrm{Na}^{+}\right)$; HRMS calcd for $\mathrm{C}_{21} \mathrm{H}_{19} \mathrm{BrN}_{2} \mathrm{O}_{4} \mathrm{Na} m / z$ 465.0426, found 465.0424; $[\alpha]_{\mathrm{D}}^{29}=144.5(c=0.15)$.

Data for methyl (3S,4aR,7S,13bS,13cS)-3-bromo-4,4-dimethyl-5-oxo-3,4,4a,5,7,8,13,13b-octahydro-3,13c-epoxybenzo[1,2]indolizino[8,7-b]indole-7-carboxylate (5j): ${ }^{1} \mathrm{H}$ NMR (300 $\mathrm{MHz}, d$-DMSO) $\delta 11.02(\mathrm{~s}, 1 \mathrm{H}), 7.45(\mathrm{~d}, J=7.7 \mathrm{~Hz}, 1 \mathrm{H}), 7.35(\mathrm{~d}, J=$ $8.0 \mathrm{~Hz}, 1 \mathrm{H}), 7.13-6.98(\mathrm{~m}, 2 \mathrm{H}), 6.98(\mathrm{~d}, J=5.6 \mathrm{~Hz}, 1 \mathrm{H}), 6.66(\mathrm{~d}, J=$ $5.6 \mathrm{~Hz}, 1 \mathrm{H}), 5.66(\mathrm{~s}, 1 \mathrm{H}), 5.28(\mathrm{~d}, J=6.6 \mathrm{~Hz}, 1 \mathrm{H}), 3.61(\mathrm{~s}, 3 \mathrm{H}), 3.30$ (d, $J=15.8 \mathrm{~Hz}, 1 \mathrm{H}), 2.94$ (ddd, $J=15.8,7.1,1.9 \mathrm{~Hz}, 1 \mathrm{H}), 2.68$ (s, $1 \mathrm{H}), 1.24(\mathrm{~s}, 3 \mathrm{H}), 1.02(\mathrm{~s}, 3 \mathrm{H}) ;{ }^{13} \mathrm{C}$ NMR $(75 \mathrm{MHz}, d$-DMSO) $\delta$ $171.8,170.7,139.9,137.4,136.3,127.9,126.9,122.4,119.7,118.8$, 112.2, 106.6, 101.8, 90.9, 57.0, 53.5, 53.4, 49.9, 47.0, 26.2, 24.3, 24.1; IR $\left(\mathrm{cm}^{-1}\right.$, neat) 1733, 1693; ESI-MS $m / z 479\left(\mathrm{M}+\mathrm{Na}^{+}\right)$; HRMS calcd for $\mathrm{C}_{22} \mathrm{H}_{21} \mathrm{BrN}_{2} \mathrm{O}_{4} \mathrm{Na} m / z$ 479.0582, found 479.0585; $[\alpha]_{\mathrm{D}}^{31}=$ $89.6(c=0.11)$.

Data for methyl (3S,4aS,7S,13bS,13cR)-4a-chloro-3-methyl5-oxo-3,4,4a,5,7,8,13,13b-octahydro-3,13c-epoxybenzo[1,2]indolizino $[8,7-b]$ indole-7-carboxylate (5k): ${ }^{1} \mathrm{H}$ NMR $(300 \mathrm{MHz}$, $\left.\mathrm{CDCl}_{3}\right) \delta 8.09(\mathrm{~s}, 1 \mathrm{H}), 7.51(\mathrm{~d}, J=7.6 \mathrm{~Hz}, 1 \mathrm{H}), 7.34(\mathrm{~d}, J=8.1 \mathrm{~Hz}$, $1 \mathrm{H}), 7.21-7.13(\mathrm{~m}, 2 \mathrm{H}), 6.78(\mathrm{~d}, J=5.7 \mathrm{~Hz}, 1 \mathrm{H}), 6.57(\mathrm{~d}, J=5.7 \mathrm{~Hz}$, $1 \mathrm{H}), 5.88(\mathrm{~s}, 1 \mathrm{H}), 5.42(\mathrm{~d}, J=6.4 \mathrm{~Hz}, 1 \mathrm{H}), 3.70(\mathrm{~s}, 3 \mathrm{H}), 3.45(\mathrm{~d}, J=$ $15.8 \mathrm{~Hz}, 1 \mathrm{H}), 3.19$ (ddd, $J=15.8,7.3,2.2 \mathrm{~Hz}, 1 \mathrm{H}), 2.60(\mathrm{~d}, J=12.8$ $\mathrm{Hz}, 1 \mathrm{H}), 1.83(\mathrm{~d}, J=12.8 \mathrm{~Hz}, 1 \mathrm{H}), 1.51(\mathrm{~s}, 3 \mathrm{H}) ;{ }^{13} \mathrm{C}$ NMR $(75 \mathrm{MHz}$, $\left.\mathrm{CDCl}_{3}\right) \delta 171.4,170.4,143.6,137.2,131.7,127.0,126.7,123.0,120.3$, 118.9, 111.6, 108.2, 92.6, 88.7, 70.8, 53.2, 53.1, 49.9, 45.3, 23.9, 19.1; IR $\left(\mathrm{cm}^{-1}\right.$, neat) 1743, 1693; ESI-MS $m / z 421\left(\mathrm{M}+\mathrm{Na}^{+}\right)$; HRMS calcd for $\mathrm{C}_{21} \mathrm{H}_{19} \mathrm{ClN}_{2} \mathrm{O}_{4} m / z$ 398.1033, found 398.1037; $[\alpha]_{\mathrm{D}}^{32}=8.9$ (c $=0.45$ ).

Data for methyl $(3 S, 4 a S, 7 S, 13 b S, 13 c R)-4 a-c h l o r o-3-e t h y l-5-$ oxo-3,4,4a,5,7,8,13,13b-octahydro-3,13c-epoxybenzo[1,2]indolizino $[8,7-b]$ indole-7-carboxylate $(5 \mathrm{l}):{ }^{1} \mathrm{H}$ NMR $(300 \mathrm{MHz}$, $\left.\mathrm{CDCl}_{3}\right) \delta 8.04(\mathrm{~s}, 1 \mathrm{H}), 7.52(\mathrm{~d}, J=7.6 \mathrm{~Hz}, 1 \mathrm{H}), 7.35(\mathrm{~d}, J=8.0 \mathrm{~Hz}$ $1 \mathrm{H}), 7.23-7.11(\mathrm{~m}, 2 \mathrm{H}), 6.80(\mathrm{~d}, J=5.7 \mathrm{~Hz}, 1 \mathrm{H}), 6.65(\mathrm{~d}, J=5.7 \mathrm{~Hz}$, $1 \mathrm{H}), 5.88(\mathrm{~s}, 1 \mathrm{H}), 5.42(\mathrm{~d}, J=6.7 \mathrm{~Hz}, 1 \mathrm{H}), 3.70(\mathrm{~s}, 3 \mathrm{H}), 3.45(\mathrm{~d}, J=$ $15.8 \mathrm{~Hz}, 1 \mathrm{H}), 3.19$ (ddd, $J=15.8,7.2,2.1 \mathrm{~Hz}, 1 \mathrm{H}), 2.61(\mathrm{~d}, J=12.8$ $\mathrm{Hz}, 1 \mathrm{H}), 1.82(\mathrm{q}, J=7.6 \mathrm{~Hz}, 2 \mathrm{H}), 1.79(\mathrm{~d}, J=12.8 \mathrm{~Hz}, 1 \mathrm{H}), 0.93(\mathrm{t}, J$ $=7.6 \mathrm{~Hz}, 3 \mathrm{H}) ;{ }^{13} \mathrm{C} \mathrm{NMR}\left(75 \mathrm{MHz}, \mathrm{CDCl}_{3}\right) \delta 171.4,170.6,141.9$, $137.2,131.9,127.0,126.8,122.9,120.2,118.9,111.7,108.0,92.7,92.4$, 70.7, 53.2, 53.2, 50.0, 43.3, 25.9, 24.0, 9.3; IR ( $\mathrm{cm}^{-1}$, neat) 1745, 1693; ESI-MS $m / z 435\left(\mathrm{M}+\mathrm{Na}^{+}\right)$; HRMS calcd for $\mathrm{C}_{22} \mathrm{H}_{21} \mathrm{ClN}_{2} \mathrm{O}_{4} \mathrm{~m} / z$ 412.1190, found 412.1192; $[\alpha]_{\mathrm{D}}^{33}=10.7(c=0.51)$.

Data for methyl $(3 R, 4 \mathrm{a} S, 7 S, 13 \mathrm{bS}, 13 \mathrm{c} R)$-3-bromo-4a-chloro5-oxo-3,4,4a,5,7,8,13,13b-octahydro-3,13c-epoxybenzo[1,2]indolizino[8,7-b]indole-7-carboxylate (5m): ${ }^{1} \mathrm{H}$ NMR $(300 \mathrm{MHz}$, $\left.\mathrm{CDCl}_{3}\right) \delta 8.54(\mathrm{~s}, 1 \mathrm{H}), 7.53(\mathrm{~d}, J=7.4 \mathrm{~Hz}, 1 \mathrm{H}), 7.33(\mathrm{~d}, J=7.4 \mathrm{~Hz}$, $1 \mathrm{H}), 7.24-7.13(\mathrm{~m}, 2 \mathrm{H}), 6.82(\mathrm{~d}, J=5.6 \mathrm{~Hz}, 1 \mathrm{H}), 6.73(\mathrm{~d}, J=5.6 \mathrm{~Hz}$, $1 \mathrm{H}), 5.98(\mathrm{~s}, 1 \mathrm{H}), 5.44(\mathrm{~d}, J=6.6 \mathrm{~Hz}, 1 \mathrm{H}), 3.68(\mathrm{~s}, 3 \mathrm{H}), 3.48(\mathrm{~d}, J=$ $15.9 \mathrm{~Hz}, 1 \mathrm{H}), 3.25$ (ddd, $J=15.9,7.2,2.0 \mathrm{~Hz}, 1 \mathrm{H}), 3.18(\mathrm{~d}, J=13.1$ $\mathrm{Hz}, 1 \mathrm{H}), 2.37(\mathrm{~d}, J=13.1 \mathrm{~Hz}, 1 \mathrm{H}) ;{ }^{13} \mathrm{C}$ NMR $\left(75 \mathrm{MHz}, \mathrm{CDCl}_{3}\right) \delta$ $171.2,169.2,143.7,137.3,132.6,126.9,125.3,123.2,120.4,119.0$, 111.8, 108.4, 92.2, 88.8, 70.0, 53.4, 53.0, 50.3, 50.0, 24.0; IR ( $\mathrm{cm}^{-1}$, neat) 1745,1698 ; ESI-MS $m / z 484\left(\mathrm{M}+\mathrm{Na}^{+}\right)$; HRMS calcd for $\mathrm{C}_{20} \mathrm{H}_{16} \mathrm{BrClN}_{2} \mathrm{O}_{4} \mathrm{~m} / z$ 461.9982, found 461.9980; $[\alpha]_{\mathrm{D}}^{33}=46.1(c=$ 0.28 ).

Methyl (3S)-2-Acryloyl-1-(furan-2-yl)-2,3,4,9-tetrahydro-1 $H$ $\beta$-carboline-3-carboxylate (cis-4). The ${ }^{1} \mathrm{H}$ NMR spectrum of compound cis-4 shows double peaks for all proton signals. To clarify the possibility of a diasteromeric mixture, we carried out HPLC analysis. The HPLC analysis of cis- $\mathbf{4}$ shows a single peak. The mass analysis also supports the cis-4 structure. To confirm the structure of the unreacted compound, we also carried out an X-ray crystallographic study. The X-ray analysis unambiguously confirms the cis-4 structure and rules out the possibility of a diastereomeic mixture. After a literature study, it was contemplated that the "double-peak nature" of the NMR spectrum could be due to the possibility of rotamers of compound cis-4. To clarify this, we took advantage of a variabletemperature ${ }^{1} \mathrm{H}$ NMR study where at high temperature interconversion between two rotamers is rapid. ${ }^{21}$ To test the dynamics of the interconversion between the two rotamers, a variable-temperature
NMR study was carried out in $\mathrm{CDCl}_{3}$ solution for compound cis-4 at seven different temperatures from -10 to $+50{ }^{\circ} \mathrm{C}$. All double peaks were merged at $50{ }^{\circ} \mathrm{C}$ in ${ }^{1} \mathrm{H}$ NMR, suggesting the presence of conformational isomers (rotamers) of cis-4. The regular ${ }^{1} \mathrm{H}$ NMR spectra clearly displayed that two rotational isomers are present in a $2: 3$ ratio. The X-ray analysis of cis- 4 showed that the crystal has the cis form. Data for cis-4: ${ }^{1} \mathrm{H}$ NMR $\left(300 \mathrm{MHz}, \mathrm{CDCl}_{3}\right) \delta 8.73(\mathrm{~s}, 1 \mathrm{H}), 8.61$ $(\mathrm{s}, 1 \mathrm{H}), 7.62-7.59(\mathrm{~m}, 2 \mathrm{H}), 7.43(\mathrm{~s}, 1 \mathrm{H}), 7.29(\mathrm{~d}, J=7.8 \mathrm{~Hz}, 2 \mathrm{H})$, $7.25-7.06(\mathrm{~m}, 4 \mathrm{H}), 6.98(\mathrm{~s}, 1 \mathrm{H}), 6.70(\mathrm{dd}, J=16.3,11.2 \mathrm{~Hz}, 1 \mathrm{H})$, $6.47(\mathrm{~d}, J=16.3 \mathrm{~Hz}, 2 \mathrm{H}), 6.29-6.18(\mathrm{~m}, 2 \mathrm{H}), 6.41-6.33(\mathrm{~m}, 2 \mathrm{H})$, 6.09-5.99 (m, 2H), $5.95(\mathrm{~s}, 1 \mathrm{H}), 5.87(\mathrm{~d}, J=10.8 \mathrm{~Hz}, 1 \mathrm{H}), 5.81(\mathrm{~d}, J$ $=11.3 \mathrm{~Hz}, 1 \mathrm{H}), 5.08(\mathrm{~s}, 1 \mathrm{H}), 5.06(\mathrm{~s}, 1 \mathrm{H}), 3.64(\mathrm{dd}, J=16.8,16.3 \mathrm{~Hz}$, $2 \mathrm{H}), 3.38(\mathrm{~s}, 3 \mathrm{H}), 3.22(\mathrm{~s}, 3 \mathrm{H}), 3.00(\mathrm{dd}, J=16.3,6.9 \mathrm{~Hz}, 2 \mathrm{H}) ;{ }^{13} \mathrm{C}$ NMR $\left(75 \mathrm{MHz}, \mathrm{CDCl}_{3}\right) \delta 171.6,170.8,168.1,167.6,152.5,152.3$, $143.5,143.1,137.0,130.0,129.1,128.9,128.8,128.3,127.3,126.7$, $126.7,123.1,122.8,120.1,120.0,119.3,118.9,111.6,111.6,110.8$, $110.5,110.5,110.2,109.4,107.4,77.8$ 54.0, 53.3, 52.9, 50.0, 49.0, 46.2, 22.4, 21.4; ESI-MS $m / z 373.1\left(\mathrm{M}+\mathrm{Na}^{+}\right)$.

General Procedure for the Synthesis of Multicyclic Indole Alkaloids $\mathbf{5 n - p}$. For the synthesis of hexacyclic indole alkaloids $\mathbf{5 n -}$ $\mathbf{p}$, acryloyl chloride was replaced by maleic anhydride. To a solution of tetrahydro- $\beta$-carboline $3(0.2 \mathrm{~g}, 0.6 \mathrm{mmol}, 1.0$ equiv $)$ in dichloroethane $(20 \mathrm{~mL})$ were added maleic anhydride $(0.9 \mathrm{mmol}, 1.5$ equiv) and triethylamine $(3.0 \mathrm{mmol}, 5.0$ equiv), and the reaction mixture was refluxed for $6 \mathrm{~h}$. The crude product was then purified by column chromatography to obtain multicyclic indole alkaloids 5n (0.163 g, $62 \%$ yield) and cis-4n ( $0.065 \mathrm{~g}, 25 \%$ yield).

All other derivatives, $\mathbf{5 o}, \mathbf{p}$ and cis-4o,p, were synthesized by the same above-mentioned procedure.

Data for (3R,4S,4aR,7S,13bS,13cS)-7-(methoxycarbonyl)-3methyl-5-oxo-3,4,4a,5,7,8,13,13b-octahydro-3, $13 \mathrm{c}-$ epoxybenzo[ $[1,2]$ indolizino[8,7-b]indole-4-carboxylic acid $(5 \mathrm{n})$ : ${ }^{1} \mathrm{H}$ NMR (300 MHz, $d$-DMSO) $\delta 10.95(\mathrm{~s}, 1 \mathrm{H}), 7.43(\mathrm{~d}, J=7.6 \mathrm{~Hz}$, $1 \mathrm{H}), 7.32(\mathrm{~d}, J=8.0 \mathrm{~Hz}, 1 \mathrm{H}), 7.10-6.95(\mathrm{~m}, 2 \mathrm{H}), 6.91(\mathrm{~d}, J=5.5 \mathrm{~Hz}$, $1 \mathrm{H}), 6.32(\mathrm{~d}, J=5.5 \mathrm{~Hz}, 1 \mathrm{H}), 5.66(\mathrm{~s}, 1 \mathrm{H}), 5.21(\mathrm{~d}, J=6.5 \mathrm{~Hz}, 1 \mathrm{H})$, 3.59 (s, $3 \mathrm{H}), 3.29$ (d, $J=15.7 \mathrm{~Hz}, 1 \mathrm{H}), 3.15(\mathrm{~d}, J=9.0 \mathrm{~Hz}, 1 \mathrm{H}), 2.86$ $(\mathrm{m}, 1 \mathrm{H}), 2.58(\mathrm{~d}, J=9.0 \mathrm{~Hz}, 1 \mathrm{H}), 1.40(\mathrm{~s}, 3 \mathrm{H}) ;{ }^{13} \mathrm{C}$ NMR $(75 \mathrm{MHz}$, $d$-DMSO) $\delta 172.3,172.0,170.7,140.3,137.4,137.3,129.0,127.0$, 122.2 , 119.6, 118.7, 112.2, 106.3, 91.0, 89.3, 55.0, 53.7, 53.4, 49.8, 48.9, 24.3, 16.5; IR $\left(\mathrm{cm}^{-1}\right.$, neat) 1733, 1695; ESI-MS $m / z 431\left(\mathrm{M}+\mathrm{Na}^{+}\right)$; HRMS calcd for $\mathrm{C}_{22} \mathrm{H}_{20} \mathrm{~N}_{2} \mathrm{O}_{6} \mathrm{Na} m / z$ 431.1219, found 431.1223; $[\alpha]_{\mathrm{D}}^{29}$ $=8.1(c=0.19)$.

Data for $(3 R, 4 S, 4 \mathrm{a} R, 7 \mathrm{~T}, 13 \mathrm{bS}, 13 \mathrm{cS})$-3-ethyl-7-(methoxycarbonyl)-5-oxo-3,4,4a,5,7,8,13,13b-octahydro-3, $13 \mathrm{c}$ epoxybenzo[1,2]indolizino[8,7-b]indole-4-carboxylic acid (5o): ${ }^{1} \mathrm{H}$ NMR (300 MHz, $d$-DMSO) $\delta 10.98(\mathrm{~s}, 1 \mathrm{H}), 7.45(\mathrm{~d}, J=7.6 \mathrm{~Hz}$, $1 \mathrm{H}), 7.34(\mathrm{~d}, J=8.1 \mathrm{~Hz}, 1 \mathrm{H}), 7.12-6.97(\mathrm{~m}, 2 \mathrm{H}), 6.95(\mathrm{~d}, J=5.6 \mathrm{~Hz}$, $1 \mathrm{H}), 6.49(\mathrm{~d}, J=5.6 \mathrm{~Hz}, 1 \mathrm{H}), 5.68(\mathrm{~s}, 1 \mathrm{H}), 5.23(\mathrm{~d}, J=6.6 \mathrm{~Hz}, 1 \mathrm{H})$ $3.61(\mathrm{~s}, 3 \mathrm{H}), 3.31(\mathrm{~d}, J=15.9 \mathrm{~Hz}, 1 \mathrm{H}), 3.17(\mathrm{~d}, J=9.0 \mathrm{~Hz}, 1 \mathrm{H}), 2.87$ $(\mathrm{m}, 1 \mathrm{H}), 2.62(\mathrm{~d}, J=9.0 \mathrm{~Hz}, 1 \mathrm{H}), 1.92-1.66(\mathrm{~m}, 2 \mathrm{H}), 0.89(\mathrm{t}, J=7.5$ $\mathrm{Hz}, 3 \mathrm{H}) ;{ }^{13} \mathrm{C}$ NMR $(75 \mathrm{MHz}, d$-DMSO) $\delta 172.4,172.0,170.7,138.2$, $137.7,137.3,129.0,127.0,122.2,119.6,118.7,112.2,106.3,93.5,90.8$, 54.8, 53.9, 53.4, 49.8, 47.7, 24.3, 23.1, 10.1; IR ( $\mathrm{cm}^{-1}$, neat) 1731, 1689; ESI-MS $m / z 445\left(\mathrm{M}+\mathrm{Na}^{+}\right)$; HRMS calcd for $\mathrm{C}_{23} \mathrm{H}_{22} \mathrm{~N}_{2} \mathrm{O}_{6} \mathrm{Na}$ $m / z$ 445.1375, found 445.1373; $[\alpha]_{\mathrm{D}}^{31}=88.0(c=1.5)$.

Data for $(3 S, 4 R, 4 \mathrm{a} R, 7 \mathrm{~T}, 13 \mathrm{bS}, 13 \mathrm{cS})$-3-bromo-7-(methoxycarbonyl)-5-oxo-3,4,4a,5,7,8,13,13b-octahydro-3,13cepoxybenzo[1,2]indolizino[8,7-b]indole-4-carboxylic acid (5p): ${ }^{1} \mathrm{H}$ NMR (300 MHz, $d$-DMSO) $\delta 11.08(\mathrm{~s}, 1 \mathrm{H}), 7.47(\mathrm{~d}, J=7.7 \mathrm{~Hz}$, $1 \mathrm{H}), 7.36(\mathrm{~d}, J=8.0 \mathrm{~Hz}, 1 \mathrm{H}), 7.11-7.01(\mathrm{~m}, 2 \mathrm{H}), 7.06(\mathrm{~d}, J=5.5 \mathrm{~Hz}$, $1 \mathrm{H}), 6.59(\mathrm{~d}, J=5.5 \mathrm{~Hz}, 1 \mathrm{H}), 5.78(\mathrm{~s}, 1 \mathrm{H}), 5.24(\mathrm{~d}, J=6.5 \mathrm{~Hz}, 1 \mathrm{H})$, $3.61(\mathrm{~s}, 3 \mathrm{H}), 3.37-3.29(\mathrm{~m}, 2 \mathrm{H}), 3.06(\mathrm{~d}, J=8.9,1 \mathrm{H}), 2.90(\mathrm{~m}, 1 \mathrm{H})$; ${ }^{13} \mathrm{C}$ NMR (75 MHz, $d$-DMSO) $\delta 171.8,170.5,169.7,140.5,138.6$, $137.3,128.0,126.9,122.5,119.7,118.9,112.2,106.6,91.5,90.2,54.5$ 53.6, 53.4, 52.3, 50.1, 24.3; IR ( $\mathrm{cm}^{-1}$, neat) 1739, 1671; ESI-MS $\mathrm{m} / z$ $495\left(\mathrm{M}+\mathrm{Na}^{+}\right)$; HRMS calcd for $\mathrm{C}_{21} \mathrm{H}_{17} \mathrm{BrN}_{2} \mathrm{O}_{6} \mathrm{Na} m / z$ 495.0168, found 495.0170; $[\alpha]_{\mathrm{D}}^{29}=159.6(c=0.14)$.

General Procedure for the Synthesis of Multicyclic Indole Alkaloid 7a. Sodium hydride ( $1.8 \mathrm{mmol}, 3.0$ equiv) was added to the solution of tetrahydro- $\beta$-carboline 3 ( $0.2 \mathrm{~g}, 0.6 \mathrm{mmol}, 1.0$ equiv) in dry 
$\mathrm{CH}_{2} \mathrm{Cl}_{2}(20 \mathrm{~mL})$ at room temperature. Then allyl bromide or propargyl bromide ( $1.2 \mathrm{mmol}, 2.0$ equiv) was added to the reaction mixture in a dropwise manner, and the reaction mixture was refluxed for $8 \mathrm{~h}$. The reaction was quenched by ice-water and extracted with dichloromethane. The extracts were concentrated under reduced pressure, and the crude product was purified by column chromatography to afford 6a (0.192 g, 87\% yield). Compound 6a was further refluxed in dichloroethane $(20 \mathrm{~mL})$ for $6 \mathrm{~h}$. The reaction mixture was concentrated under reduce pressure, and the crude product was purified by column chromatography to furnish exo-7a $(0.076 \mathrm{~g}, 40 \%$ yield) and endo-7a $(0.052 \mathrm{~g}, 30 \%$ yield $)$ in quantitative yields along with cis-6a $(0.052 \mathrm{~g}, 30 \%$ yield).

All other intermediates, $\mathbf{6 b}-\mathbf{d}$, were synthesized by the same abovementioned procedure.

Data for methyl (1S,3S)-1-(5-bromofuran-2-yl)-2-prop-2-en1-yl-2,3,4,9-tetrahydro-1 $\mathrm{H}-\boldsymbol{\beta}$-carboline-3-carboxylate (6a): ${ }^{1} \mathrm{H}$ NMR $\left(300 \mathrm{MHz}, \mathrm{CDCl}_{3}\right) \delta 7.81(\mathrm{~s}, 1 \mathrm{H}), 7.64(\mathrm{~d}, J=7.3 \mathrm{~Hz}, 1 \mathrm{H})$, $7.31(\mathrm{~d}, J=7.3 \mathrm{~Hz}, 1 \mathrm{H}), 7.21-7.10(\mathrm{~m}, 2 \mathrm{H}), 6.32-6.27(\mathrm{~m}, 2 \mathrm{H}), 5.90$ $(\mathrm{m}, 1 \mathrm{H}), 5.47(\mathrm{~s}, 1 \mathrm{H}), 5.30-5.17(\mathrm{~m}, 2 \mathrm{H}), 4.17(\mathrm{t}, J=5.4 \mathrm{~Hz}, 1 \mathrm{H})$, $3.69(\mathrm{~s}, 3 \mathrm{H}), 3.50-3.36(\mathrm{~m}, 2 \mathrm{H}), 3.21(\mathrm{~d}, J=5.4 \mathrm{~Hz}, 2 \mathrm{H}) ;{ }^{13} \mathrm{C} \mathrm{NMR}$ $\left(75 \mathrm{MHz}, \mathrm{CDCl}_{3}\right) \delta 173.7,156.6,136.7,136.2,131.4,127.2,122.4$, 122.1, 119.9, 118.8, 118.1, 112.6, 111.5, 111.4, 107.7, 57.3, 54.9, 54.2, 52.1, 23.6; ESI-MS $m / z 415\left(\mathrm{M}+\mathrm{H}^{+}\right)$; HRMS calcd for $\mathrm{C}_{20} \mathrm{H}_{20} \mathrm{BrN}_{2} \mathrm{O}_{3} m / z$ 415.0657, found $415.0655(\mathrm{M}+\mathrm{H})^{+}$.

Data for methyl (1S,3S)-1-(5-bromofuran-2-yl)-2-(3-methylbut-2-en-1-yl)-2,3,4,9-tetrahydro- $1 H$ - $\beta$-carboline-3-carboxylate (6b): ${ }^{1} \mathrm{H}$ NMR $\left(300 \mathrm{MHz}, \mathrm{CDCl}_{3}\right) \delta 7.95(\mathrm{~s}, 1 \mathrm{H}), 7.58(\mathrm{~d}, J=$ $6.6 \mathrm{~Hz}, 1 \mathrm{H}), 7.28(\mathrm{~d}, J=7.2 \mathrm{~Hz}, 1 \mathrm{H}), 7.20-7.14(\mathrm{~m}, 2 \mathrm{H}), 6.29(\mathrm{~s}$, $2 \mathrm{H}), 5.49(\mathrm{~s}, 1 \mathrm{H}), 5.35(\mathrm{dt}, J=6.5,1.2 \mathrm{~Hz}, 1 \mathrm{H}), 4.23(\mathrm{t}, J=5.4 \mathrm{~Hz}$, $1 \mathrm{H}), 3.70(\mathrm{~s}, 3 \mathrm{H}), 3.54-3.37(\mathrm{~m}, 2 \mathrm{H}), 3.24-3.22(\mathrm{~m}, 2 \mathrm{H}), 1.81(\mathrm{~s}$, $3 \mathrm{H}), 1.62(\mathrm{~s}, 3 \mathrm{H}) ;{ }^{13} \mathrm{C} \mathrm{NMR}\left(75 \mathrm{MHz}, \mathrm{CDCl}_{3}\right) \delta 174.7,156.9,136.3$, $131.5,122.5,122.0,122.0,121.8,120.9,119.0,112.6,112.4,112.4$, $111.5,107.6,57.1,55.1,52.3,48.7,26.5,23.6,18.3$; ESI-MS $m / z 443$ $\left(\mathrm{M}+\mathrm{H}^{+}\right)$; HRMS calcd for $\mathrm{C}_{22} \mathrm{H}_{24} \mathrm{BrN}_{2} \mathrm{O}_{3} \mathrm{~m} / z$ 443.0970, found $443.0959(\mathrm{M}+\mathrm{H})^{+}$.

Data for methyl (1S,3S)-2-(3-methylbut-2-en-1-yl)-1-(5methylfuran-2-yl)-2,3,4,9-tetrahydro- $1 \mathrm{H}$ - $\beta$-carboline-3-carboxylate (6c): ${ }^{1} \mathrm{H} \mathrm{NMR}\left(300 \mathrm{MHz}, \mathrm{CDCl}_{3}\right) \delta 7.71(\mathrm{~s}, 1 \mathrm{H}), 7.55(\mathrm{~d}, J=$ $6.9 \mathrm{~Hz}, 1 \mathrm{H}), 7.27(\mathrm{~d}, J=6.9 \mathrm{~Hz}, 1 \mathrm{H}), 7.20-7.09(\mathrm{~m}, 2 \mathrm{H}), 6.20(\mathrm{~d}, J=$ $3.0 \mathrm{~Hz}, 1 \mathrm{H}), 5.94(\mathrm{~d}, J=3.0 \mathrm{~Hz}, 1 \mathrm{H}), 5.46(\mathrm{~s}, 1 \mathrm{H}), 5.34(\mathrm{t}, J=5.4 \mathrm{~Hz}$, $1 \mathrm{H}), 4.24(\mathrm{t}, J=5.4 \mathrm{~Hz}, 1 \mathrm{H}), 3.68(\mathrm{~s}, 3 \mathrm{H}), 3.45(\mathrm{dd}, J=13.5,8.1 \mathrm{~Hz}$ $1 \mathrm{H}), 3.35(\mathrm{dd}, J=13.5,6.3 \mathrm{~Hz}, 1 \mathrm{H}), 3.21(\mathrm{~d}, J=5.4 \mathrm{~Hz}, 2 \mathrm{H}), 2.28(\mathrm{~s}$, $3 \mathrm{H}), 1.78(\mathrm{~s}, 3 \mathrm{H}), 1.58(\mathrm{~s}, 3 \mathrm{H}) ;{ }^{13} \mathrm{C} \mathrm{NMR}\left(75 \mathrm{MHz}, \mathrm{CDCl}_{3}\right) \delta 174.2$, $153.0,152.3,136.7,136.6,132.5,127.4,122.1,122.0,119.8,118.7$, 111.3, 110.4, 107.3, 106.5, 56.9, 54.9, 51.9, 48.5, 26.4, 23.7, 18.3, 14.2; ESI-MS $m / z 379\left(\mathrm{M}+\mathrm{H}^{+}\right)$; HRMS calcd for $\mathrm{C}_{23} \mathrm{H}_{27} \mathrm{~N}_{2} \mathrm{O}_{3} \mathrm{~m} / z$ 379.2022, found $379.2009(\mathrm{M}+\mathrm{H})^{+}$.

Data for methyl (1S,3S)-1-(5-bromofuran-2-yl)-2-prop-2-yn1-yl-2,3,4,9-tetrahydro-1 $\mathrm{H}$ - $\boldsymbol{\beta}$-carboline-3-carboxylate (6d): ${ }^{1} \mathrm{H}$ NMR $\left(300 \mathrm{MHz}, \mathrm{CDCl}_{3}\right) \delta 7.80(\mathrm{~s}, 1 \mathrm{H}), 7.55(\mathrm{~d}, J=6.9 \mathrm{~Hz}, 1 \mathrm{H})$, $7.29(\mathrm{~d}, J=6.6 \mathrm{~Hz}, 1 \mathrm{H}), 7.23-7.11(\mathrm{~m}, 2 \mathrm{H}), 6.36(\mathrm{~d}, J=5.7 \mathrm{~Hz}, 1 \mathrm{H})$, $6.32(\mathrm{~d}, J=5.7 \mathrm{~Hz}, 1 \mathrm{H}), 5.58(\mathrm{~s}, 1 \mathrm{H}), 4.45(\mathrm{t}, J=4.8 \mathrm{~Hz}, 1 \mathrm{H}), 3.79$ $(\mathrm{dd}, J=16.5,2.4 \mathrm{~Hz}, 1 \mathrm{H}), 3.70(\mathrm{~s}, 3 \mathrm{H}), 3.64(\mathrm{dd}, J=16.5,2.4 \mathrm{~Hz}$, $1 \mathrm{H}), 3.27(\mathrm{~m}, 2 \mathrm{H}), 2.32(\mathrm{t}, J=2.4 \mathrm{~Hz}, 1 \mathrm{H}) ;{ }^{13} \mathrm{C} \mathrm{NMR}(75 \mathrm{MHz}$, $\left.\mathrm{CDCl}_{3}\right) \delta 173.4,155.4,136.8,130.9,127.1,122.6,122.5,120.0,118.8$, $112.7,112.5,111.5,107.3,80.3,75.6,57.7,54.8,52.2,41.3$, 24.2; ESIMS $m / z 435\left(\mathrm{M}+\mathrm{Na}^{+}\right)$; HRMS calcd for $\mathrm{C}_{20} \mathrm{H}_{18} \mathrm{BrN}_{2} \mathrm{O}_{3} \mathrm{~m} / z$ 413.0501, found $413.489(\mathrm{M}+\mathrm{H})^{+}$.

Data for methyl (3R,4aS,7S,13bS,13cS)-3-bromo$3,4,4 a, 5,7,8,13,13 \mathrm{~b}$-octahydro-3,13c-epoxybenzo[1,2]indolizino[8,7-b]indole-7-carboxylate (endo-7a): ${ }^{1} \mathrm{H}$ NMR (300 $\left.\mathrm{MHz}, \mathrm{CDCl}_{3}\right) \delta 7.81(\mathrm{~s}, 1 \mathrm{H}), 7.51(\mathrm{~d}, J=7.2 \mathrm{~Hz}, 1 \mathrm{H}), 7.31(\mathrm{~d}, J=7.2$ $\mathrm{Hz}, 1 \mathrm{H}), 7.19-7.06(\mathrm{~m}, 2 \mathrm{H}), 6.71(\mathrm{~d}, J=5.4 \mathrm{~Hz}, 1 \mathrm{H}), 6.47(\mathrm{~d}, J=5.4$ $\mathrm{Hz}, 1 \mathrm{H}), 5.37(\mathrm{~s}, 1 \mathrm{H}), 4.14(\mathrm{dd}, J=10.2,6.6 \mathrm{~Hz}, 1 \mathrm{H}), 3.65(\mathrm{~s}, 3 \mathrm{H})$, $3.35(\mathrm{dd}, J=7.8,6.6 \mathrm{~Hz}, 1 \mathrm{H}), 3.23-3.20(\mathrm{~m}, 2 \mathrm{H}), 2.85(\mathrm{dd}, J=10.2$, $7.8 \mathrm{~Hz}, 1 \mathrm{H}), 2.48(\mathrm{~m}, 1 \mathrm{H}), 2.05(\mathrm{~d}, J=5.7 \mathrm{~Hz}, 2 \mathrm{H}) ;{ }^{13} \mathrm{C}$ NMR $(75$ $\left.\mathrm{MHz} \mathrm{CDCl}_{3}\right) \delta 173.2,141.4,137.6,137.1,130.0,127.4,122.2,119.6$, 118.6, 111.5, 107.3, 96.0, 90.5, 58.5, 56.2, 54.9, 52.6, 46.6, 40.8, 20.0; IR $\left(\mathrm{cm}^{-1}\right.$, neat $) 1735,1432$; ESI-MS $m / z 437\left(\mathrm{M}+\mathrm{Na}^{+}\right)$; HRMS calcd for $\mathrm{C}_{20} \mathrm{H}_{19} \mathrm{BrN}_{2} \mathrm{O}_{3} \mathrm{Na} m / z$ 437.0477, found 437.0475; $[\alpha]_{\mathrm{D}}^{28}=$ $120.0(c=0.18)$.
Data for methyl $(3 S, 4 \mathrm{a} R, 7 S, 13 \mathrm{~b} S, 13 \mathrm{c} R)$-3-bromo$3,4,4 a, 5,7,8,13,13$ b-octahydro-3,13c-epoxybenzo[ 1,2$]-$ indolizino[8,7-b]indole-7-carboxylate (exo-7a): ${ }^{1} \mathrm{H}$ NMR (300 $\left.\mathrm{MHz}, \mathrm{CDCl}_{3}\right) \delta 8.11(\mathrm{~s}, 1 \mathrm{H}), 7.54(\mathrm{~d}, J=7.8 \mathrm{~Hz}, 1 \mathrm{H}), 7.38(\mathrm{~d}, J=7.8$ $\mathrm{Hz}, 1 \mathrm{H}), 7.25-7.12(\mathrm{~m}, 2 \mathrm{H}), 6.43,6.42(\mathrm{abq}, J=5.7 \mathrm{~Hz}, 2 \mathrm{H}), 4.90(\mathrm{~s}$, $1 \mathrm{H}), 3.97(\mathrm{t}, J=5.4 \mathrm{~Hz}, 1 \mathrm{H}), 3.71(\mathrm{~s}, 3 \mathrm{H}), 3.35(\mathrm{dd}, J=11.1,8.1 \mathrm{~Hz}$, $1 \mathrm{H}), 3.27-3.15(\mathrm{~m}, 3 \mathrm{H}), 2.30(\mathrm{~m}, 1 \mathrm{H}), 2.20-2.06(\mathrm{~m}, 2 \mathrm{H}) ;{ }^{13} \mathrm{C}$ NMR $\left(75 \mathrm{MHz}, \mathrm{CDCl}_{3}\right) \delta 173.6,141.0,136.9,135.5,129.5,127.1$, $122.8,120.2$, 118.7, 111.5, 109.1, 98.9, 89.5, 59.7, 57.4, 56.7, 52.6, 46.6, 42.2, 23.4; IR ( $\mathrm{cm}^{-1}$, neat) 1725, 1442; ESI-MS $m / z 437\left(\mathrm{M}+\mathrm{Na}^{+}\right)$; HRMS calcd for $\mathrm{C}_{20} \mathrm{H}_{19} \mathrm{BrN}_{2} \mathrm{O}_{3} \mathrm{Na} m / z$ 437.0477, found 437.0476; $[\alpha]_{\mathrm{D}}^{31}=-5.2(c=0.1)$.

General Procedure for the Polymer-Supported Synthesis of Multicyclic Indole Alkaloids 5. The polyethylene glycol-supported tetrahydro- $\beta$-carboline conjugate $\mathbf{8}$ was initially prepared through three synthetic steps from L-tryptophan methyl ester (1) following the procedures developed earlier by our group. ${ }^{20}$ Acryloyl chloride (2.5 equiv, $0.43 \mathrm{mmol})$ and triethylamine $(0.12 \mathrm{~mL}, 5.0$ equiv, $0.85 \mathrm{mmol})$ were added to the solution of polyethylene glycol-supported tetrahydro- $\beta$-carboline conjugate $8(1.1 \mathrm{~g}, 0.17 \mathrm{mmol})$ in dichloromethane $(20 \mathrm{~mL})$, and the reaction mixture was stirred at room temperature for $2 \mathrm{~h}$. The reaction mixture was then diluted with cold ether to precipitate the polymer-bound compound, which was filtered through a fritted funnel. The residue was washed with cold ether (50 $\mathrm{mL} \times 3)$ and dried well to give polymer-bound compounds 9 and $\mathbf{1 0}$. To a solution of polymer-bound compounds 5 and cis-4 in methanol was added $\mathrm{KCN}(0.1 \mathrm{~g})$, and the resulting mixture was stirred for $8 \mathrm{~h}$. The reaction was quenched and precipitated by cold ether. The precipitated polymer was removed by filtration, and the filtrate was concentrated under reduced pressure. The obtained crude product was then purified by silica gel column chromatography using a 2:1 mixture of hexane and ethyl acetate as the eluent, and the corresponding products 5a and cis-4a were obtained in total over two steps $(37 \mathrm{mg}$, $60 \%$ yield).

All other derivatives, $\mathbf{5 d}$ and $\mathbf{5 g}$ as well as cis-4d and cis-4g, were synthesized by the same procedure.

Investigation of Intramolecular Diels-Alder Cyclization with Thiophene Diene. The following reaction sequence illustrates intramolecular Diels-Alder cyclization with thiophene diene:

Data for methyl (1R,3S)-1-(thiophene-2-yl)-2,3,4,9-tetrahydro-1H- $\beta$-carboline-3-carboxylate (11a): $[\alpha]_{\mathrm{D}}^{27}=-39.3(c=0.6)$; ${ }^{1} \mathrm{H}$ NMR $\left(300 \mathrm{MHz}, \mathrm{CDCl}_{3}\right) \delta 7.67(\mathrm{~s}, 1 \mathrm{H}), \delta 7.56(\mathrm{dd}, J=6.7,1.7$ $\mathrm{Hz}, 1 \mathrm{H}), 7.34(\mathrm{dd}, J=5.1,0.9 \mathrm{~Hz}, 1 \mathrm{H}), 7.26(\mathrm{~m}, 1 \mathrm{H}), 7.22-7.11(\mathrm{~m}$, $3 \mathrm{H}), 7.05(\mathrm{dd}, J=5.1,3.5 \mathrm{~Hz}, 1 \mathrm{H}), 5.62(\mathrm{~s}, 1 \mathrm{H}), 3.98(\mathrm{dd}, J=11.2$, $4.3 \mathrm{~Hz}, 1 \mathrm{H}$ ), 3.85 (s, 3H), 3.24 (ddd, $J=15.2,4.3,1.9 \mathrm{~Hz}, 1 \mathrm{H}), 3.02$ $($ ddd, $J=15.2,11.2,2.5 \mathrm{~Hz}, 1 \mathrm{H}) ;{ }^{13} \mathrm{C}$ NMR $\left(75 \mathrm{MHz} \mathrm{CDCl}_{3}\right) \delta$ 173.3, 144.6, 136.5, 134.4, 127.5, 127.1, 126.6, 126.6, 122.5, 120.1, $118.8,111.5,108.8,57.3,54.3,52.8,25.8$; IR (KBr) 3379, 2916, 1732 $\mathrm{cm}^{-1}$; ESI-MS $m / z$ 335.08 $\left(\mathrm{M}+\mathrm{Na}^{+}\right)$; HRMS calcd for $\mathrm{C}_{17} \mathrm{H}_{16} \mathrm{~N}_{2} \mathrm{O}_{2} \mathrm{SNa} m / z$ 335.0830, found $335.0832(\mathrm{M}+\mathrm{Na})^{+}$.

Data for methyl (1S,3S)-1-(thiophene-2-yl)-2,3,4,9-tetrahydro-1 $\mathrm{H}$ - $\boldsymbol{\beta}$-carboline-3-carboxylate (11b): $[\alpha]_{\mathrm{D}}^{27}=-32.2(c=$ 1.17); ${ }^{1} \mathrm{H}$ NMR $\left(300 \mathrm{MHz}, \mathrm{CDCl}_{3}\right) \delta 8.10(\mathrm{~s}, 1 \mathrm{H}), \delta 7.57(\mathrm{dd}, J=6.8$, $1.4 \mathrm{~Hz}, 1 \mathrm{H}), 7.28(\mathrm{dd}, J=5.0,1.0 \mathrm{~Hz}, 1 \mathrm{H}), 7.25-7.12(\mathrm{~m}, 3 \mathrm{H}), 6.97$ $(\mathrm{dd}, J=5.0,3.5 \mathrm{~Hz}, 1 \mathrm{H}), 6.92(\mathrm{~d}, J=3.5 \mathrm{~Hz}, 1 \mathrm{H}), 5.61(\mathrm{~s}, 1 \mathrm{H}), 4.05$ (dd, $J=8.0,5.0 \mathrm{~Hz}, 1 \mathrm{H}), 3.76(\mathrm{~s}, 3 \mathrm{H}), 3.27(\mathrm{dd}, J=15.5,5.0 \mathrm{~Hz}, 1 \mathrm{H})$, 3.06 (ddd, $J=15.5,8.0,1.2 \mathrm{~Hz}, 1 \mathrm{H}) ;{ }^{13} \mathrm{C}$ NMR $\left(75 \mathrm{MHz} \mathrm{CDCl}_{3}\right) \delta$ $174.4,146.6,136.6,133.4,127.3,127.1,126.4,126.3,122.6,119.9$, $118.8,111.6,108.3,52.8,52.7,50.9,25.2$; IR (KBr) 3390, 2949, 1734 $\mathrm{cm}^{-1}$; ESI-MS $\mathrm{m} / z$ 335.08 $\left(\mathrm{M}+\mathrm{Na}^{+}\right)$; HRMS calcd for $\mathrm{C}_{17} \mathrm{H}_{16} \mathrm{~N}_{2} \mathrm{O}_{2} \mathrm{SNa} m / z$ 335.0830, found $335.0832(\mathrm{M}+\mathrm{Na})^{+}$.

Data for methyl (1R,3S)-2-acryloyl-1-(thiophene-2-yl)2,3,4,9-tetrahydro-1 $H$ - $\beta$-carboline-3-carboxylate (12a): $[\alpha]_{\mathrm{D}}^{27}=$ $+78.8(c=0.6) ;{ }^{1} \mathrm{H}$ NMR $\left(300 \mathrm{MHz}, \mathrm{CDCl}_{3}\right) \delta 8.09(\mathrm{~s}, 1 \mathrm{H}), 7.62(\mathrm{~d}$, $J=7.8 \mathrm{~Hz}, 1 \mathrm{H}), 7.33(\mathrm{~d}, J=7.4 \mathrm{~Hz}, 1 \mathrm{H}), 7.28-7.13(\mathrm{~m}, 3 \mathrm{H}), 7.07(\mathrm{~s}$, $1 \mathrm{H}), 6.83(\mathrm{~s}, 1 \mathrm{H}), 6.75-6.62(\mathrm{~m}, 2 \mathrm{H}), 6.38(\mathrm{~d}, J=16.6 \mathrm{~Hz}, 1 \mathrm{H}), 5.82$ $(\mathrm{d}, J=10.2 \mathrm{~Hz}, 1 \mathrm{H}), 5.06(\mathrm{~s}, 1 \mathrm{H}), 3.68(\mathrm{~d}, J=15.8 \mathrm{~Hz}, 1 \mathrm{H}), 3.13(\mathrm{~s}$, $3 \mathrm{H}), 3.08(\mathrm{dd}, J=15.8,7.3 \mathrm{~Hz}, 1 \mathrm{H}) ;{ }^{13} \mathrm{C}$ NMR $\left(75 \mathrm{MHz}, \mathrm{CDCl}_{3}\right) \delta$ $170.8,168.1,142.6,136.9,129.8,129.0,128.8,128.3,127.3,126.7$, $125.8,122.9,120.0,119.0,111.7,107.7,53.5,52.7,48.0,22.2$; IR 


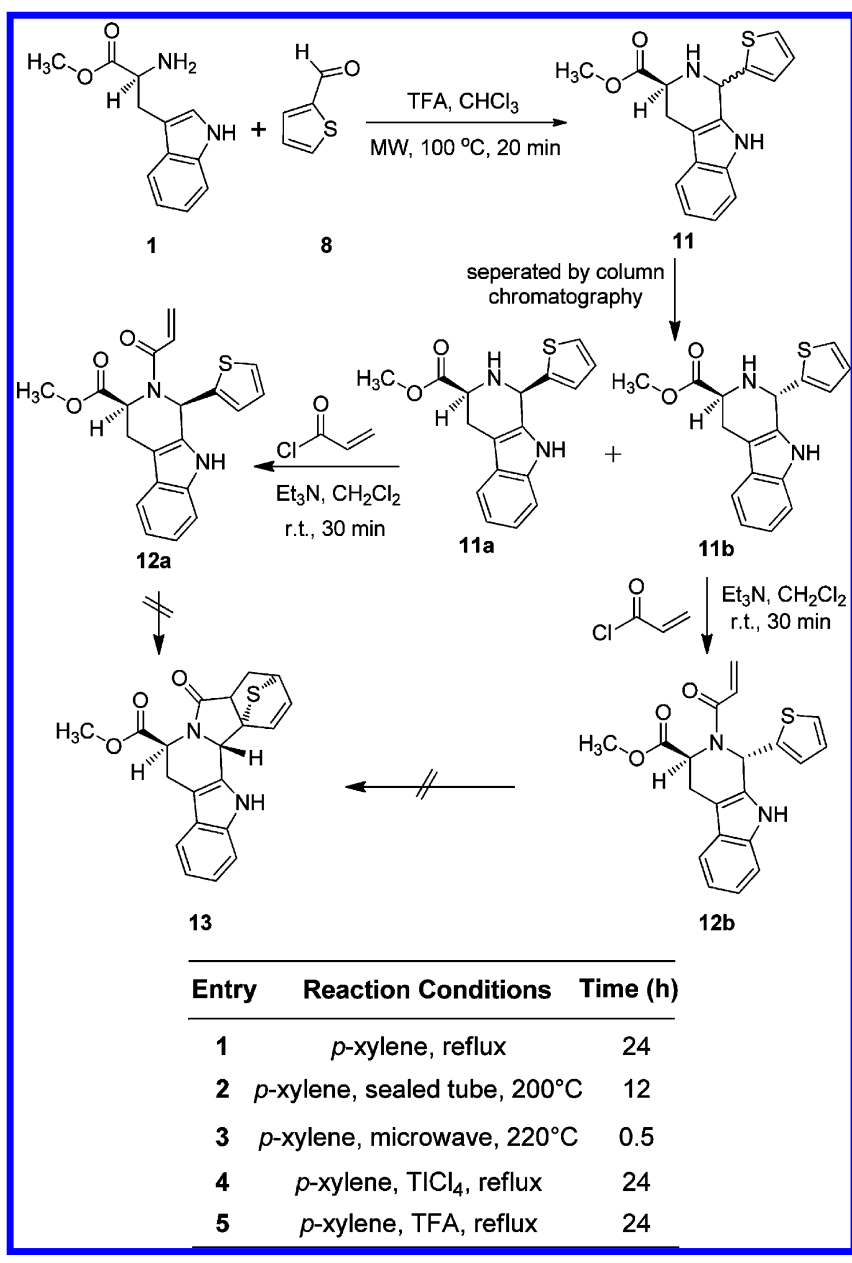

(KBr) 3315, 2949, $1738 \mathrm{~cm}^{-1}$; ESI-MS $m / z 389\left(\mathrm{M}+\mathrm{Na}^{+}\right)$; HRMS calcd for $\mathrm{C}_{20} \mathrm{H}_{18} \mathrm{~N}_{2} \mathrm{O}_{3} \mathrm{SNa} m / z$ 389.0936, found $389.0934(\mathrm{M}+\mathrm{Na})^{+}$.

Data for methyl (1S,3S)-2-acryloyl-1-(thiophene-2-yl)2,3,4,9-tetrahydro- $1 H$ - $\beta$-carboline-3-carboxylate (12b): $[\alpha]_{\mathrm{D}}^{27}=$ $-51.7(c=3.0) ;{ }^{1} \mathrm{H}$ NMR $\left(300 \mathrm{MHz}, \mathrm{CDCl}_{3}\right) \delta 7.58(\mathrm{~d}, J=7.8 \mathrm{~Hz}$, $1 \mathrm{H}), 7.37(\mathrm{~d}, J=7.5 \mathrm{~Hz}, 1 \mathrm{H}), 7.28-7.16(\mathrm{~m}, 3 \mathrm{H}), 7.06(\mathrm{~s}, 1 \mathrm{H}), 6.95$ (s, 1H), $6.77(\mathrm{~s}, 1 \mathrm{H}), 6.60(\mathrm{~s}, 1 \mathrm{H}), 6.36(\mathrm{dd}, J=16.7,1.4 \mathrm{~Hz}, 1 \mathrm{H})$, $5.74(\mathrm{dd}, J=10.6,1.4 \mathrm{~Hz}, 1 \mathrm{H}), 4.75(\mathrm{~s}, 1 \mathrm{H}), 3.65(\mathrm{~s}, 3 \mathrm{H}), 3.57(\mathrm{~m}$, $1 \mathrm{H}), 3.26(\mathrm{~m}, 1 \mathrm{H}) ;{ }^{13} \mathrm{C} \mathrm{NMR}\left(75 \mathrm{MHz}, \mathrm{CDCl}_{3}\right) \delta 171.6,168.6$, $144.7,137.1,136.9,130.1,128.6,127.4,126.6,126.5,122.9,120.2$, 118.9, 112.0, 112.0, 108.7, 54.5, 54.0, 52.9, 22.8; IR (KBr) 3323, 2950, $1738 \mathrm{~cm}^{-1}$; ESI-MS $\mathrm{m} / z 389\left(\mathrm{M}+\mathrm{Na}^{+}\right)$; HRMS calcd for $\mathrm{C}_{20} \mathrm{H}_{18} \mathrm{~N}_{2} \mathrm{O}_{3} \mathrm{SNa} m / z$ 389.0936, found $389.0933(\mathrm{M}+\mathrm{Na})^{+}$.

\section{ASSOCIATED CONTENT}

\section{S Supporting Information}

${ }^{1} \mathrm{H}$ NMR, ${ }^{13} \mathrm{C}$ NMR, LRMS, HRMS, and IR spectra of compounds $5 \mathbf{a}-\mathbf{p}, \mathbf{6}$, and $7 \mathbf{a}$ and X-ray crystallographic data and CIF data for 5o (CCDC 829262) and cis-4. This material is available free of charge via the Internet at http://pubs.acs.org.

\section{AUTHOR INFORMATION}

\section{Corresponding Author}

*E-mail: cmsun@mail.nctu.edu.tw.

\section{Notes}

The authors declare no competing financial interest.

\section{ACKNOWLEDGMENTS}

We thank Dr. I-Ting Ho for her help in carrying out variabletemperature NMR experiments. We thank the National Science Council of Taiwan for financial assistance. This study was particularly supported by "Aim for the Top University Plan" of the National Chiao Tung University and Ministry of Education, Taiwan, ROC.

\section{REFERENCES}

(1) (a) Newman, D. J.; Cragg, G. M. I. Nat. Prod. 2007, 70, 461-477. (b) Walsh, C. T.; Fischbach, M. A. I. Am. Chem. Soc. 2010, 132, 24692493.

(2) (a) Strausberg, R. L.; Schreiber, S. L. Science 2003, 300, 294-295. (b) Walsh, D. P.; Chang, Y. T. Chem. Rev. 2006, 106, 2476-2530.

(c) Ahn, Y. H.; Chang, Y. T. Acc. Chem. Res. 2007, 40, 1025-1033.

(3) Goldberg, M. R.; Robertson, D. Pharmacol. Rev. 1983, 35, 143180

(4) (a) Kronig, B.; Pittrow, D. B.; Kirch, W.; Welzel, D.; Weidinger, G. Hypertension 1997, 29, 651-658. (b) Lucas, R. A. Prog. Med. Chem. 1963, 3, 146-186.

(5) Yu, J.; Wearing, X. Z.; Cook, J. M. L. Org. Chem. 2005, 70, 39633979.

(6) Wasilke, J. C.; Obrey, S. J.; Baker, R. T.; Bazan, G. C. Chem. Rev. 2005, 105, 1001-1020.

(7) Kobayashi, M.; Suda, T.; Noguchi, K.; Tanaka, K. Angew. Chem. Int. Ed. 2011, 50, 1664-1667.

(8) Znabet, A.; Zonneveld, J.; Janssen, E.; De Kanter, F. J. J.; Helliwell, M.; Turner, N. J.; Ruijter, E.; Orru, R. V. A. Chem. Commun. 2010, 46, 7706-7708.

(9) (a) Magnus, N. A.; Ley, C. P.; Pollock, P. M.; Wepsiec, J. P. Org Lett. 2010, 12, 3700-3703. (b) Toma, T.; Kita, Y.; Fukuyama, T. I. Am. Chem. Soc. 2010, 132, 10233-10235. (c) Reymond, S.; Cossy, J. Chem. Rev. 2008, 108, 5359-5406.

(10) Maiti, B.; Chanda, K.; Sun, C. M. Org. Lett. 2009, 11, 48264829.

(11) Jung, M. E.; Min, S. J. J. Am. Chem. Soc. 2005, 127, 1083410835 .

(12) (a) Yellol, G. S.; Chung, T. W.; Sun, C. M. Chem. Commun. 2010, 46, 9170-9172. (b) Chanda, K.; Maiti, B.; Yellol, G. S.; Chien, M. H.; Kuo, M. L.; Sun, C. M. Org. Biomol. Chem. 2011, 9, 19171926. (c) Chen, C. H.; Kuo, J.; Yellol, G. S.; Sun, C. M. Chem.-Asian I. 2011, 6, 1557-1565.

(13) (a) Ungemach, F.; DiPierro, M.; Weber, R.; Cook, J. M. I. Org. Chem. 1981, 46, 164-168. (b) Bailey, P. D.; Hollinshead, S. P.; McLay, N. R.; Morgan, K.; Palmer, S. J.; Prince, S. N.; Reynolds, C. D.; Wood, S. D. I. Chem. Soc., Perkin Trans. 1 1993, 4, 431-439.

(14) (a) Fokas, D.; Yu, L.; Baldino, C. M. Mol. Diversity 2005, 9, 8189. (b) Paulvannan, K.; Hale, R.; Mesis, R.; Chen, T. Tetrahedron Lett. 2002, 43, 203-207.

(15) Jung, M. E.; Kiankarimi, M. I. Org. Chem. 1998, 63, 2968-2974.

(16) Singh, R. S.; Adachi, S.; Tanaka, F.; Yamauchi, T.; Inui, C.; Harada, T. L. Org. Chem. 2008, 73, 212-218.

(17) Garcia, J. I.; Mayoral, J. A.; Salvatella, L. Tetrahedron 1997, 53, 6057-6064.

(18) (a) Toy, P. H.; Janda, K. D. Acc. Chem. Res. 2000, 33, 546-554. (b) Dickerson, T. J.; Reed, N. N.; Janda, K. D. Chem. Rev. 2002, 102, 3325-3344.

(19) Borisov, A. V.; Detistov, O. S.; Pukhovaya, V. I.; Zhuravel, I. O.; Kovalenko, S. M. I. Comb. Chem. 2009, 11, 1023-1029.

(20) Chen, C. H.; Chang, C. M.; Chen, H. Y.; Lai, J. J.; Sun, C. M. I. Comb. Chem. 2007, 9, 618-626.

(21) Kim, Y. J.; Park, Y.; Park, K. K. I. Mol. Struct. 2006, 783, 61-65. 